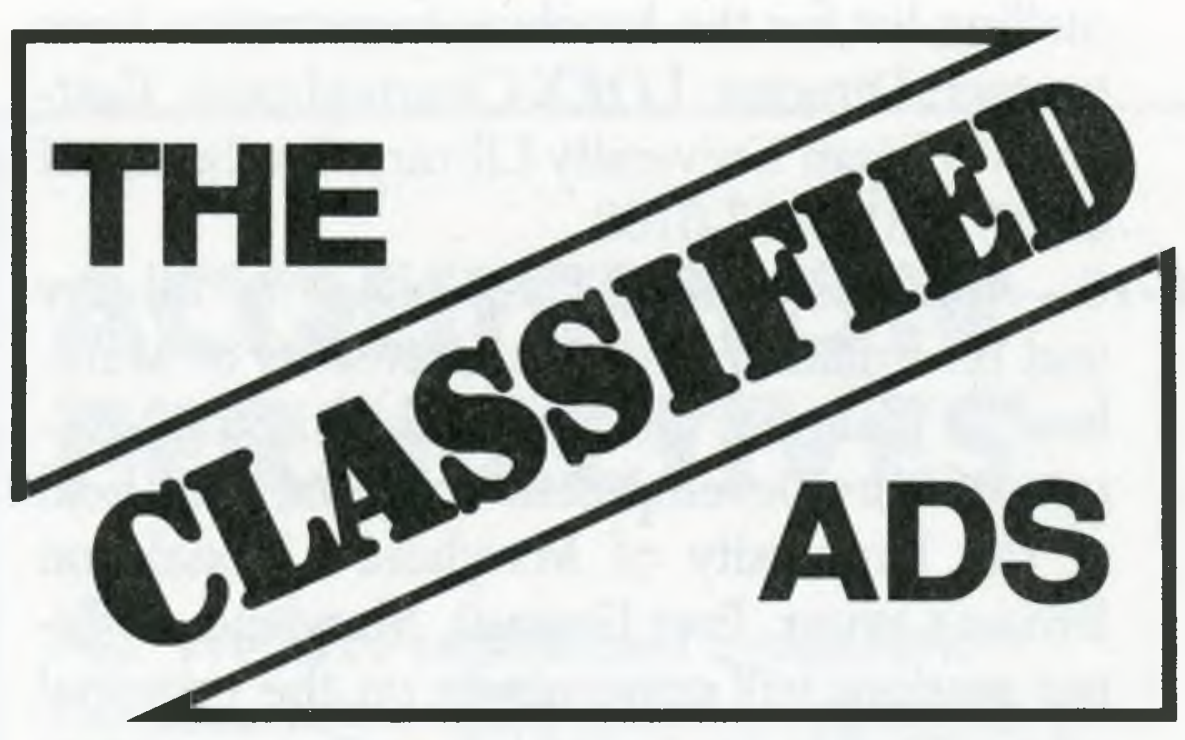

Deadlines: Orders for regular classified advertisements must reach the ACRL office on or before the second of the month preceding publication of the issue (e.g., September 2 for the October issue). Late job listings will be accepted on a space-available basis after the second of the month.

Rates: Classified advertisements are $\$ 5.75$ per line for ACRL members, $\$ 7.25$ for others. Late job notices are $\$ 13.75$ per line for members, $\$ 16.20$ for others. Organizations submitting ads will be charged according to their membership status.

Telephone: All telephone orders should be confirmed by a written order mailed to ACRL headquarters as soon as possible. Orders should be accompanied by a typewritten copy of the ad to be used in proofreading. An additional $\$ 15$ will be charged for ads taken over the phone (except late job notices or display ads).

Guidelines: For ads which list an application deadline, that date must be no sooner than the 20th day of the month in which the notice appears (e.g., October 20 for the October issue). All job announcements should include a salary figure. Job announcements will be edited to exclude discriminatory references. Applicants should be aware that the terms faculty rank and status vary in meaning among institutions.

JOBLINE: Call (312) 944-6795 for late-breaking job ads for academic and research library positions. A pre-recorded summary of positions listed with the service is revised weekly; each Friday a new tape includes all ads received by 1:00 p.m. the previous day. Each listing submitted will be carried on the recording for two weeks. The charge for each two-week listing is $\$ 30$ for ACRL members and $\$ 35$ for non-members.

Fast Job Listing Service: A special newsletter for those actively seeking positions. This service lists job postings received at ACRL headquarters four weeks before they appear in C\&RL News, as well as ads which, because of narrow deadlines, will not appear in C\&RL News. The cost of a six-month subscription is $\$ 15$ for ACRL members and $\$ 20$ for non-members.

Contact: Classified Advertising Department, ACRL, American Library Association, 50 E. Huron St., Chicago, IL 60611-2795; (312) $944-6780$

\section{FOR SALE}

PEOPLE COUNTERS, for information: 1-800-441-BOOK, library director designed and markets accurate electronic device that will count the people that enter your library with invisible beam, usable anywhere, portable or permanently, $\$ 229$ includes shipping. Full warranty for one year, Laser Counters, 120 West Walnut St. Blytheville, AR 72315. (501) 762-2431. Over 500 sold U.S. and Canada.

\section{MATERIALS WANTED}

SPACE PROBLEMS? We will buy your surplus serials, technical, scientific and historic materials. Send list for best offer to: Colfax Books, P.O. Box 380542, Denver, CO 80238.

\section{SERVICES AVAILABLE}

LET THE GOVERNMENT FINANCE your small business. Grants/ loans to $\$ 500,000$. Free recorded message: $707 / 448-0270$. (NS5)

\section{POSITIONS OPEN}

ACCESS SERVICES LIBRARIAN. A 12-month tenure-track position at California State University, Hayward, which serves 12,000 multi-ethnic students in the San Francisco Bay Area. Duties and responsibilities: directs circulation, periodical and reserve services; supervision of personnel (6 FTE staff and 45 student employees), the automated circulation system and the physical maintenance/security of 750,000 volume collection. Will participate in implementing an integrated online public access catalog, circulation and reserve system. Will participate in collection development and reference activities. Occasional evening and weekend hours required. Qualifications: ALA-accredited MLS; minimum of 3 years professional experience, preferably in an academic library; 2 years in circulation or access services (pre-MLS considered), preferably with an automated circulation system; managerial/supervisory experience required; demonstrated record of professional participation; experience working with an ethnically diverse student body. Salary range: $\$ 33,168-\$ 50,472$ depending on experience and qualifications. Send letter, resume, names, addresses and telephone numbers of 3 references to: Melissa Rose, Library Director, California State University, Hayward, Hayward, CA 94542. To be assured consideration, applications must be received before March 1, 1990. Applications from women and minorities welcome. AAVEOE. Position \#89-90 CSLIB (TT) 1.

ACQUISITIONS/COLLECTIONS LIBRARIAN, University of South Dakota Law Library. Position available mid-February, 1990. Application closing date: January 31,1990. Qualifications: Bachelor's degree, including at least one year of library science course work and two years of library work experience or an equivalent combination of education and experience. Experience with IBM PC compatible computers is required. Additional points will be awarded for experience with law libraries and legal reference sources only Desirable qualifications include knowledge of library and fiscal management; knowledge of database, WordPerfect, and spreadsheet programs; and an MLS from an ALA-accredited school. Responsibilities: Acquisition and collection developmentanalysis, supervision of library accounting records and reports, and one hour a day of reference work. Salary: $\$ 16,932-\$ 19,053$. Send request for application, resume with names of references, and college transcript to Office of Personnel Services, 207 Slagle Hall, University of South Dakota, Vermillion, SD 57069; (605) 6775671. EOE.

ASSISTANT UNIVERSITY LIBRARIAN, PERSONNEL. Coordinates recruiting, career development, performance appraisal, and personnel policies and procedures for 62 librarians, 150 nonacademic staff and 350 student employees. Manages library personnel office and implements affirmative action. Familiarity with government regulations affecting employment, experience with collective bargaining; good communication skills. Requires MLS or relevant library experience and education and experience in management or related personnel fields preferably in an academic environment. Salary range is $\$ 44,100-\$ 70,100$. Send resumes by February 1, 1990 to Joseph Boissé, University Librarian, University of California, Santa Barbara, CA 93106. UCSB is an affirmative action, equal opportunity employer. Proof of U.S. citizenship or eligibility for U.S. employment required prior to employment.

ASSOCIATE LIBRARY DIRECTOR. The University of West Florida Library invites applications and nominations for the new position of Associate Director. Under the leadership of the Director of Libraries the Associate Director shares in overseeing the services, 
resources and operations of the library and assumes chief administrative responsibility in the absence of the Director. The Associate works jointly with the Director in developing policy, overseeing services and operations, preparing budgets, counseling personnel, and resolving problems. Required are an ALA-accredited MLS, and seven years increasingly responsible administrative experience in an academic library including supervision of a division/department comprised of librarians and support staff. Extensive knowledge of librarianship, competency in budget preparation and control, skill in motivating staff. Effective interpersonal and communication skills, understanding of academic teaching and research needs, evidence of professional development, service, and participation in professional associations. Advanced academic achievement desired. The University of West Florida is one of nine institutions in the State University System, all of which use NOTIS. The library serves over 7,000 students with a collection of more than 500,000 volumes and subscriptions to over 4,000 journals. Staff number 19 librarians and 29 support personnel. Benefits: Salary $\$ 42,000$ to $\$ 47,000$, TIAACREF or other retirements, no state or local income taxes. Send nominations or letter of application, resume and names of three professional references by February 28, 1990, to: Director's Office, John C. Pace Library, The University of West Florida, 11000 University Parkway, Pensacola, FL 32514-5750. UWF is an Equal Opportunity, Affirmative Action Employer.

AUTHORITY CONTROL/CATALOG MANAGEMENT LIBRARIAN, Ball State University, Muncie, Indiana. Plans, directs, monitors, and evaluates the section responsible for precataloging searching, authority control and conflict resolution, and record maintenance in University Libraries' online (NOTIS) and card catalogs. Trains, directs, and evaluates three FTE staff; resolves conflicts in name, subject, series, and uniform title headings in online catalog; participates in development and documentation of authority control and bibliographic maintenance policies and procedures; performs original and/or complex copy cataloging of monographs. This position reports to the Head of Cataloging Services. Minimum qualifications: MLS from ALA-accredited program or equivalent; at least two years professional cataloging experience, using OCLC or a comparable bibliographic utility; knowledge of MARC bibliographic and authorities formats, AACR2, LC rule interpretations, LCSH and Classification, and principles of authority control; strong organizational and problem solving skills; ability to work constructively with colleagues; effective written and oral communication skills. Preferred qualifications: Experience with NOTIS or another integrated online library system; supervisory experience in a cataloging environment; working knowledge of one or more Western European languages. Terms: Fiscal year contract with 24 days vacation, excellent fringe benefits, possible tenure-track appointment with faculty status depending on credentials. Salary negotiable: $\$ 22,000$ minimum. Application: Send a letter of application, resume, graduate transcripts (unofficial copies acceptable), and a list of three references, including addresses and telephone numbers to: Nyal Williams, Chairperson, Department of Library Service, Ball State University, Muncie, IN 47306. Consideration of credentials will begin immediately and will continue until the position is filled. Can conduct preliminary interviews at ALA midwinter meeting in Chicago. Ball State University practices equal opportunity in education and employment.

BIBLIOGRAPHER FOR PROFESSIONAL STUDIES and AsSistant Professor. The University of Illinois at Chicago seeks a Bibliographer for Professional Studies who knows and understands the social science literature as it pertains to research and instruction in the fields of Business, Economics, Education, Urban Planning and Policy, and Physical Education and Recreation. The Bibliographer for Professional studies plays a crucial role as library collections grow to support expanding Ph.D. and master's programs. UIC's collections include over 1.7 million volumes and over 18,000 serial subscriptions. The current library materials budget is 3.7 million. The library of the University of Illinois at Chicago is well known for its outstanding faculty, its collections and staff, and its interest in experimentation and change. Specific Responsibilities: Identifies and selects library materials, both current and retrospective, that support the teaching and research programs of UIC; works with the faculties of the College of Business Administration, College of Education, College of Health, Physical Education and Recreation, and School of Urban Planning and Policy; discusses current issues in collection management, acquisitions, and aca- demic programs with members of the faculty and other colleges; works closely with the other bibliographers in the Collections Development Department; reports to the Principal Bibliographer. Minimum Qualifications: Master's degree in Library Science from a program accredited by the American Library Association; minimum of two years of professional Library experience or equivalent professional experience; knowledge of the literature of one or more of the above fields as evidenced by experience in collection development, acquisitions, and/or reference services; evidence of professional involvement within academic librarianship; evidence of ability to meet University standards in research, publication, and professional service commensurate with tenure. Salary/Rank/ Contract: Salary and rank dependent upon qualifications and experience; salary from $\$ 25,000$; faculty status; twelve-month appointment; 24 days vacation; 12 days annual sick leave with additional disability benefits; 11 paid holidays; paid medical coverage (coverage for dependents may be purchased); dental and life insurance; participation in the State Universities Retirement System compulsory ( $8 \%$ of salary is withheld and is tax exempt until withdrawal); no Social Security coverage but Medicare payment

\section{Salary guide}

Listed below are the minimum starting salary figures recommended by 16 state library organizations for professional library posts in these states. Job seekers and employers should consider these recommended minimums, as well as other salary surveys (such as the survey in the October 15, 1988 issue of Library Journal, the ALA Survey of Librarian Salaries, the annual $A R L$ Salary Survey, or the annual CUPA Administrative Compensation Survey) when evaluating professional vacancies. For more information, contact the ALA Office for Library Personnel Services.

$\begin{array}{lr}\begin{array}{l}\text { Connecticut } \\ \text { Indiana }\end{array} & \begin{array}{r}\$ 23,310 \\ \text { varies } \\ \text { lowa }\end{array} \\ \$ 19,619 \\ \text { Kansas } & \$ 17,500^{*} \\ \text { Louisiana } & \$ 20,000 \\ \text { Maine } & \text { varies } \\ \text { Massachusetts } & \$ 27,554^{*} \\ \text { New Hamphsire } & \$ 17,500 \\ \text { New Jersey } & \$ 24,200 \\ \text { New York } & \text { varies* } \\ \text { North Carolina } & \$ 20,832 \\ \text { Ohio } & \$ 20,024 \\ \text { Pennsylvania } & \$ 23,700^{*} \\ \text { Rhode Island } & \$ 22,500 \\ \text { South Carolina } & \text { varies* } \\ \text { South Dakota } & \$ 20,000 \\ \text { Vermont } & \$ 20,500 \\ \text { West Virginia } & \$ 20,000 \\ \text { Wisconsin } & \$ 23,700\end{array}$

*Rather than establish one statewide salary minimum, some state associations have adopted a formula based on such variables as comparable salaries for public school teachers in each community or the grade level of a professional librarian post. In these cases, you may wish to contact the state association for minimum salary information. 
required; physical examination at University Health Service is required upon appointment. For fullest consideration apply by: January 31, 1990. Apply, with supporting resume and the names of at least three references, to: Darlene M. Ziolkowski, Personnel Librarian, University of Illinois at Chicago, Box 8198, Chicago, IL 60680. The University of Illinois is an affirmative action, equal opportunity employer.

BIBLIOGRAPHER/CATALOGER. Search extended. The Kierkegaard Library at St. Olaf College seeks a professional bibliographer/cataloger to carry out cataloging of a 9,000-volume special collection during a 2-year period, with funding provided by a NEH grant. Facility with LC cataloguing procedure, AACR II, and OCLC necessary. Knowledge of some or all of the following would be helpful: German, Scandinavian languages, classical languages, philosophy, theology. Salary dependent upon qualifications and experience, with $\$ 30,000$ minimum. Apply as soon as possible to Cynthia W. Lund, Assistant Curator, Study and Publication Center, Kierkegaard Library, St. Olaf College, Northfield, MN 55057. An AA/EOE

BIBLIOGRAPHERS (3). The University of Maryland College Park Libraries invites nominations and applications for three new bibliographer positions: Bibliographer (Business, Economics, Law,
Criminal Justice), Librarian I. Responsibilities: Provides direct support for campus curricula, teaching and research in developing library collections in: Business, Economics, Law, Criminal Justice. Nature of collection management work includes: selection of library materials, analysis of collections for strengths and weaknesses; formulation and application of collecting policies; monitoring of expenditures; developing and maintaining close working relationships with faculty and other users, with the book trade world, and with other library staff; coordinates collection management activities of selectors in allied disciplines. UMCP Libraries is an ARL member. Qualifications: Required: MLS from an ALA-accredited program. Graduate degree in one of the subject areas described above. Working knowledge of one of the following languages: French, German, Italian, Russian, or Spanish. Experience: Required: Minimum three years professional experience, preferably in collection development. Preferred: Collection development experience in ARL Library, including collection analysis, collection development policy formulation and application; work experience in dealing with the book trade; demonstrated ability to deal successfully with a broad range of library functions, ability to interact effectively with library staff and diverse clientele, and ability to communicate effectively in oral and written form. Bibliographer (Germanic and Slavic Languages and Literatures, Religion, Philosophy, Jewish Studies), Librarian I. Responsibilities: Provides direct support for campus

\title{
THREE POSITIONS
}

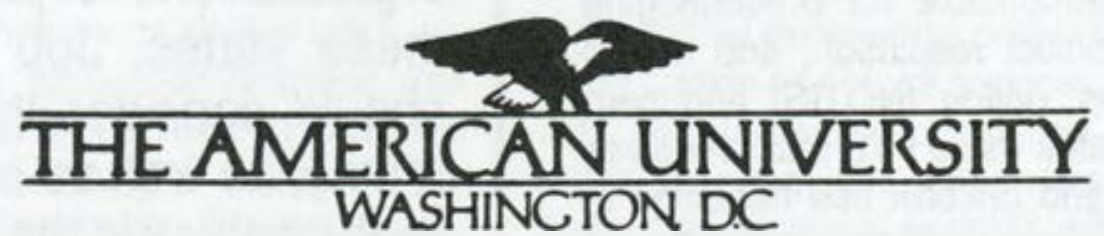

\section{Reference Librarian}

Tenure-track position available immediately. Rank open (Assistant or Associate Librarian).

Responsibilities: General reference duties, some bibliographic instruction and collection development. Some evening and weekend service is expected.

Required: ALA-accredited MLS. Preferred: Two years professional experience and subject specialization in business or natural sciences. Salary: Minimum $\$ 24,000$ depending on qualifications and experience.

Systems Librarian.

Tenure-track position available immediately. Rank open (Assistant or Associate Librarian). This position is for a department head reporting to the University Librarian.

Qualifications: Required: ALA-accredited MLS, four years professional and/or automation experience, excellent communication skills, and demonstrated ability to work with people. Experience with NOTIS and supervision of staff highly desirable.

Responsibilities: Coordinate planning, implementation and enhancements of integrated library system in consultation with Library, University Computing Center and Washington Research Library Consortium staff. Oversee set-up and maintenance of microcomputers in library. Salary: Minimum $\$ 35,000$ depending on qualifications and experience.

University Archivist/Head, Special Collections.

Tenure-track position available. Rank open (Assistant or Associate Librarian). This position is for a department head reporting to the University Librarian.

Qualifications: Required: ALA-accredited MLS, two years archive or special collections experience, excellent verbal and written communication skills. Second masters degree, supervisory experience and familiarity with preservation highly desirable.

Responsibilities: Administers and maintains the University Archives; including acquiring, classifying, preserving, and retrieving for researchers archival materials. Responsible for indexing, processing, maintaining, and preserving the Special Collections. Salary: Minimum $\$ 30,000$ depending on qualifications and experience.

Application deadline: January 20, 1990 (February 16, 1990 for Archivist). Submit resume and names of three references to:

\author{
Patricia A. Wand \\ University Librarian \\ The American University Library \\ 4400 Massachusetts Ave., N.W. \\ Washington, DC20016-8046
}

Women and minorities are encouraged to apply. The American University is an EOE/AA employer. 


\section{ASSISTANT DIRECTOR FOR AUTOMATION AND TECHNICAL OPERATIONS}

\author{
Bloomsburg University \\ of Pennsylvania
}

Responsible for administration of library automation operations (including implementation of new PALS subsystems), administration of Technical Services units, and management of preservation activities; responsible for administration of library operations in the absence of the Dean of Library Services.

Requirements: ALA-accredited MLS; 4 years' professional experience in technical services or library systems, preferably in academic/research libraries; management experience demonstrating strong management skills; demonstrated abilities in oral and written communication; broad knowledge of academic library automation. Preferred: Additional graduate studies in related field.

Starting date: Preferably by July 1990. Rank: Manager 4. Anticipated minimum salary: $\$ 35,000$. Liberal fringe benefits. Send application, curriculum vitae, and names and addresses of three references by February 13, 1990, to:

\section{Marilou W. Zeller Chairperson, Search and Screen Committee Harvey A. Andruss Library Bloomsburg University Bloomsburg, PA 17815}

Bloomsburg University is an affirmative action, equal opportunity employer. Blacks, Hispanics, women and all other protected class members are especially encouraged to apply.

curricula, teaching and research in developing library collections in: Germanic and Slavic Languages and Literatures, Religion, Philosophy, Jewish Studies. Nature of collection management work includes: selection of library materials, analysis of collections for strengths and weaknesses; formulation and application of collecting policies; monitoring of expenditures; developing and maintaining close working relationships with faculty and other users, with the book trade world, and with other library staff; coordinates collection management activities of selectors in allied disciplines. UMCP Libraries is an ARL member. Qualifications: Required: MLS from an ALA-accredited program. Graduate degree in one of the subject areas described above. Language facility in German, and Russian required: Hebrew preferred. Experience: Required: Minimum three years professional experience, preferably in collection development. Preferred: Collection development experience in ARL Library, including collection analysis, collection development policy formulation and application; work experience in dealing with the book trade; demonstrated ability to deal successfully with a broad range of library functions, ability to interact effectively with library staff and diverse clientele, and ability to communicate effectively in oral and written form. Bibliographer (Government and Politics, Journalism, Public and Urban Affairs), Librarian I. Responsibilities: Provides direct support for campus curricula, teaching and research in developing library collections in: Government and
Politics, Journalism, Public and Urban Affairs. Nature of collection management work includes: selection of library materials, analysis of collections for strengths and weaknesses; formulation and application of collecting policies; monitoring of expenditures; developing and maintaining close working relationships with faculty and other users, with the book trade world, and with other library staff; coordinates collection management activities of selectors in allied disciplines. UMCP Libraries is an ARL member. Qualifications: Required: MLS from an ALA-accredited program.,Graduate degree in one of the subject areas described above. Working knowledge of one of the following languages: French, German, Italian, Russian, or Spanish. Experience: Required: Minimum three years professional experience, preferably in collection development. Preferred: Collection development experience in ARL Library, including collection analysis, collection development policy formulation and application; work experience in dealing with the book trade; demonstrated ability to deal successfully with a broad range of library functions, ability to interact effectively with library staff and diverse clientele, and ability to communicate effectively in oral and written form. Salary for all three positions: \$28,220$\$ 39,405$. Salary commensurate with experience. Excellent fringe benefits. For full consideration, submit resume and names/addresses of 3 references by February 28, 1990, to: Marjorie Simon, Library Personnel Office, McKeldin Library, University of Maryland, College Park, MD 20742-7011. The University of Maryland is an affirmative action, equal opportunity employer.

\section{BIBLIOGRAPHIC INSTRUCTION COORDINATOR/REFER}

ENCE LIBRARIAN. The Kerr Library at Oregon State University seeks a librarian to assume primary responsibility for library instruction activities at all levels. This will include coordination of orientation, tours, basic and subject oriented instruction for all library users including undergraduate and graduate students. The position also has reference and collection development responsibilities, as well as committee and special project assignments. Reference work will include reference service to students, staff or faculty from a central reference area; this will include the use of the OCLC and RLIN systems, CD-ROM databases, online readyreference and the use of the Library's online catalog. This may include occasional night or weekend work. This position is a 12month tenure-track faculty appointment; research and publication are necessary for continuing appointment, promotion and tenure. Appointment will be at assistant professor rank for candidates with a second subject masters degree. ALA-accredited MLS, two years academic library experience, demonstrated interest in library instruction and strong oral and written communication skills are required for consideration. Minimum of $\$ 25,000$ for a 12-month appointment. Applications must be postmarked by January 31 , 1990. Please send a letter of application, a resume, and the names and phone numbers of three references to: Robert Lawrence, Chair, Search Committee, Kerr Library, Oregon State University, Corvallis, OR $97331-4501$. Oregon State University is an equal opportunity, affirmative action employer; applications from women, minorities, and disabled persons are especially welcome.

BIOMEDICAL ONLINE SERVICES COORDINATOR. Faculty position in academic medical center library. Minimum requirements: MLS from an ALA-accredited school; 3+ years medical reference/ online teaching experience; strong communications, team builder. Minimum salary: $\$ 28,500$, excellent fringe benefits. Letter of application, resume, three references to: Search Committee, University of New Mexico, Medical Center Library, Albuquerque, NM 87131. EOE/AA employer.

CATALOG LIBRARIAN at Arizona State University, which offers the opportunity to work within the environment of an innovative and highly automated research library. Responsibilities include cataloging in the social sciences and/or humanities, dependent on departmental needs and the subject and language background of the successful candidate; participation in the planning, governance and general management of the Department of Original Cataloging and Special Languages; and, potentially, the training and supervision of classified staff. Required: ALA-accredited MLS degree; broad academic background in the social sciences and/or humanities; knowledge of AACR2, LCSH, LC classification system and MARC format; demonstrated interpersonal and communication skills; ability to catalog accurately materials in any Roman alphabet language. Preferred: Original cataloging experience in a research library (either professional or pre-professional); experience with a bibliographic utility; supervisory and training experience; 


\title{
ASSISTANT DIRECTOR FOR AUTOMATED SYSTEMS
}

\author{
lowa State University
}

Working within a team of four other Assistant Directors and the Dean, this new position will have broad responsibility for creating policy, developing applications, and coordinating operations in the area of information technology. This includes implementation of all modules of the NOTIS integrated system and indexing/abstracting software, as well as general policy and technical support responsibility for microcomputer hardware and software and library telecommunications systems and local area networks. Responsible for various information delivery projects with campus units and with the National Agricultural Library. Hires and oversees systems staff, coordinates Library automation systems/projects. Prepares appropriate budgets and serves as liaison with the Computation Center and the Administrative Data Processing Center.

Required: ALA-accredited MLS or master's degree in a comparable field; five years increasing responsibility for library automation in a major academic library; demonstrated planning, communication, interpersonal, and management skills; competency and currency in library automation, including knowledge of OCLC, major integrated online systems, and microcomputer/CD-ROM applications, ability to view issues from a Library-wide perspective, ability to meet promotion and tenure criteria.

Preferred: Experience with mainframe library systems, NOTIS and IBM environments particularly desirable; knowledge of telecommunications and local area networks as they relate to library systems; some experience with programming.

Salary and Benefits: $\$ 45,000$ minimum, competitive benefits.

lowa State offers a positive environmentfor career growth and challenge. Situated on a beautiful campus, the recently remodeled and expanded Library actively serves a community of over 25,000 students and supports nationally recognized collections in excess of 1.7 million volumes, 2 million microforms and 21,000 current serial subscriptions. A fully integrated Library system is being installed. The Library is a member of ARL, CRL, BCR, and OCLC. Ames is a community of 50,000 located 35 miles from Des Moines, the state capital. The city supports quality schools and outstanding cultural attractions.

Application: Review of applications will begin February 9, 1990. Submit letter, resume, and the names, addresses, and telephone numbers of three current references to:

\author{
William K. Black \\ Assistant Director for Administrative Services and Personnel \\ lowa State University \\ 302 Parks Library \\ Ames, IA, 50011-2140
}

lowa state University has a strong commitment to equal opportunity and affirmative action. Members of protected classes are especially encouraged to apply. lowa State University is an Equal Opportunity, Affirmative Action Employer

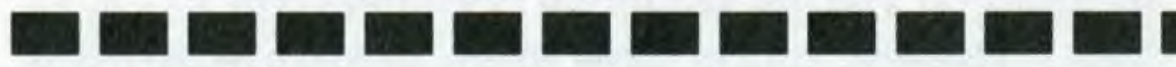 \\ ability to work with materials in Southeast Asian languages. Salary; $\$ 21,000$ and up, dependent on qualifications (but essentially an entry-level position). To apply: Send letter of application, resume, and the names, addresses, and telephone numbers of four recent references to: Constance Corey, Associate Dean of University Libraries, Hayden Library, Arizona State University, Tempe, AZ 85287-1006; (Phone 602/965-3417). Recruitment will remain open until the position is filled, with review of applications beginning January 15,1990 . ASU is an affirmative-action, equal-opportunity employer.}

CATALOG LIBRARIAN, Joyner Library, East Carolina University. Responsibilities: assist in reclassification and retrospective conversion of serials; other cataloging responsibilities as assigned. This is a 12 month fixed term faculty position and reports to the Coordinator of Technical Services. Salary $\$ 23,000$ minimum, depending on qualifications. Requirements: ALA-accredited master's in library science; working knowledge of AACR2, LC rule interpretations, LCSH, LC classification. Good oral and written communication skills; ability to work effectively with all levels of staff; ability to work well independently. Preferred: Knowledge of at least one modern European language; second master's degree; familiarity with OCLC standards; cataloging experience with an online bibliographic database. East Carolina University's libraries serve a campus community of over 16,000 students and 950 faculty. The University is a constituent institution of the sixteencampus University of North Carolina system. Screening of applications will begin March 1, 1990 and continue until position is filled. Send letter of application, resume, copies of transcripts, and three letters of reference to: Jo Ann Bell, Acting Director of Academic Library Services, Joyner Library, East Carolina University, Greenville, NC 27858-4353. Official transcripts from each college or university attended will be required prior to any offer of employment. Federal law requires proper documentation of identity and employability at the time of emploment. East Carolina University is an affirmative action, equal opportunity employer and, as such encourages applications from women, blacks, and other minorities.

CATALOG LIBRARIAN. Pacific Lutheran University seeks Catalog Librarian with ALA-accredited degree. Faculty status, tenure eligibility, and excellent benefits. Twelve-month appointment. Salary range: $\$ 20,750-\$ 25,000$, depending on qualifications. Responsibilities include original and advanced copy cataloging and classification with special emphasis on audio-visual materials, catalog and file maintenance, some collection development, and 


\title{
FOUR REFERENCE LIBRARIANS/BIBLIOGRAPHERS
}

\author{
The University of Houston Libraries
}

The University of Houston Libraries invite applications for four reference librarian/bibliographer positions: Business, Social Sciences, and two Science Reference Librarians. We seek creative talented individuals who desire to work in an environment where services are expanding and where there is considerable scope for planning and implementing new program initiatives, including the application of new technologies to the delivery of services.

General responsibilities: Responsible for collection development, user education, and computerized database searching in assigned disciplines. Provides service at the Information Desk, including some weekend and evening hours. Serves as the Library's resource person for faculty and other individuals in assigned areas of collection development.

Requirements: Master's degree from an ALA-accredited library school required. Excellent communication skills and strong service orientation essential.

Specific requirements: Business: Coursework or reference experience in Business Administration, Economics, or Hotel and Restaurant Management. Social Sciences: Coursework or reference experience in Education, Mexican-American Studies, Sociology or Anthropology. Knowledge of Mexican-American Studies highly desirable. Sciences: Interest in developing skills in physical sciences reference.

Salary and Benefits: $\$ 20,500$ minimum. Excellent benefits package including choice of retirement programs.

Library Information: The University of Houston Libraries holdings exceed 1.6 million volumes, with a materials budget of $\$ 2.2$ million and total staff of 175 . The Library is a member of ARL.

Application procedure: Review of applications will begin immediately and continue until a suitable candidate is appointed. Send letter of application, names of three references, and resume to:

\section{Dana C. Rooks \\ Assistant Director for Administration \\ University of Houston Libraries Houston, TX77204-2091}

Equal opportunity employer.

assisting in related operations of Technical Services Department. Qualifications include working knowledge of AACR2 and standard cataloging practices, familiarity with automated library systems, and ability to work with WLN or other bibliographic utility. Reading knowledge of a foreign language, preferably German or Scandinavian. Some experience preferred but not essential. Furnish letter, resume, undergraduate and graduate transcripts, three or more letters of reference and/or current placement file. Send to: John W. Heussman, Director, Mortvedt Library, Pacific Lutheran University, Tacoma, WA 98447. Deadline for receipt of all materials is February 15. Starting date is March 15 , or as arranged. AA EOE.

CATALOG LIBRARIAN. Search reopened. Duties: Management of cataloging operations, database, and staff; original cataloging of monographs, serials and non-book materials; some reference desk duties. Required: MLS from an ALA-accredited library school; three years library cataloging experience; comprehensive knowledge of LC classification and subject headings, and MARC formats, OCLC or other bibliographic utility. Desirable: Supervisory experience; familarity with integrated systems. Salary: Minimum $\$ 27,000$ for a 12-month/year tenure track faculty appointment. Benefits: TIAACREF; 22 days vacation. Application: Send letter of application, a resume, and the names and phone numbers of three references to Ingrid Schierling, Head of Technical Services, Library, University of Colorado at Colorado Springs, P.O. Box 7150, Colorado Springs, CO 80933-7150. Application deadline: February 1,1990 . The University of Colorado is an AAVEOE.

CATALOG/RETROSPECTIVE CONVERSION LIBRARIAN, Pembroke State University, a campus of the University of North Carolina. To begin February 1990. Will conduct the retrospective conversion project for the LS/2000, including all steps of the process. Evening and reference relief work, OCLC cataloging knowledge required; reference and retrospective conversion experience desirable. ALA-accredited MLS required; salary range $\$ 20,000-\$ 25,000$. Send letter of application, resume, and three letters of recommendation to: Elinor Bridges, Director of Library Services, Mary Livermore Library, Pembroke State University, Pembroke, NC 28372. Preference given to those who apply by January 18,1990 . AAEOE.

COLLECTION DEVELOPMENT LIBRARIAN, Georgetown University Library. (Search reopened) This person is responsible for the planning, implementing and overseeing of the Library's collection development program. Responsibilities include: establishing measures of collection strengths and weaknesses; formulating collection development plans for academic subjects; evaluating ongoing and proposed academic programs for collection impact. Candidates are expected to have knowledge of trends and issues in the development of academic research collections, including resource sharing. We require a minimum of five years of significan and relevant experience in an academic library, two of which must have been in collection development. A demonstrated capacity to work effectively and collegially with library and faculty colleagues and to communicate effectively both orally and in writing are essential. An MLS from an ALA-accredited school is mandatory. Minimum salary is $\$ 32,000$, with faculty status and excellent fringe benefits. Send resume to: James DeLancey, Georgetown University Library, P.O. Box 37445, Washington, DC 20013. Georgetown University is an affirmative action, equal opportunity employer.

COLLECTION DEVELOPMENT LIBRARIAN. Search re-opened. University of Arkansas at Little Rock, Ottenheimer Library. Responsible for selection, analysis, and balance of the university 


\section{HEAD, ACCESS SERVICES DEPARTMENT}

\author{
lowa State University
}

Reporting to the Assistant Director for Public Services, the Head of Access Services is a major post providing leadership in a service-directed environment. Responsibility for organization, staffing, budgeting and operation of Circulation, Interlibrary Loan, Periodical Room, Photoduplication, Reserve, and Stacks Maintenance. Administration of public service activities in branch reading rooms. Responsibility for eight supervisors, twenty-nine staff and thirty FTE student assistants. Major role in planning and implementing system-wide automated circulation (NOTIS). Participates in divisional planning and serves on Dean's Council.

Required: ALA accredited MLS; minimum of three years experience in a major academic library; effective management, supervisory communication and interpersonal skills; understanding of and commitment to library automation; ability to view issues broadly; commitment to equal opportunity and affirmative action; ability to meet promotion and tenure standards.

Preferred: Knowledge of automated circulation systems (particularly NOTIS) and Interlibrary Loan practices, experience with administration of branch library facilities. Salary and benefits: $\$ 33,000$ minimum. Competitive benefits.

lowa State offers a positive environment for career growth and challenge. Situated on a beautiful campus, the recently remodeled and expanded Library actively serves a community of over 25,000 students and supports nationally recognized collections in excess of 1.7 million volumes, 2 million microforms and 21,000 current serial subscriptions. A fully integrated Library system is in the process of being installed. The Library is a member of ARL, CRL, BCR, and OCLC. Ames is a community of 50,000 located 35 miles from Des Moines, the state capital. The city supports quality schools and outstanding cultural attractions.

Application: Review of applications will begin February 9,1990 . Submit letter, resume and names, addresses and telephone numbers of 3 references to:

\section{William K. Black \\ Assistant Director for Administrative Services and Personnel lowa State University \\ 302 Parks Library \\ Ames, IA 50011-2140 \\ (515) 294-1442}

lowa State University has a strong commitment to equal opportunity and affirmative action. Members of protected classes are especially encouraged to apply. lowa State University is an Equal Opportunity, Affirmative Action Employer. library's collections; works closely with faculty members in all departments, colleges, and schools; prepares reports on library support for courses and programs offered by the institution; prepares grant proposals; works closely with professional as well as clerical staff of library; recommends annual distribution of materials money to library administration. Reports to the Assistant Director for Instructional and Public Services. Requirements: ALA-MLS; 2nd Master's desirable; three years library experience preferred; excellent oral and written communications skills; demonstrated ability to establish beneficial relationships with faculty, co-workers, patrons, and donors in an academic environment. Salary: dependent upon experience and qualifications with $\$ 25,000$ minimum for 12-month appointment. Faculty rank and tenure eligibility; benefits include TIAACREF. Position available immediately. Deadline for nominations and applications is February 15, 1990. Send resume, listing names, addresses, and phone numbers of three references to: Kathy Sanders, Chair, Search Committee, Ottenheimer Library, University of Arkansas at Little Rock, $2801 \mathrm{~S}$. University, Little Rock, AR 72204. Applications will be subject to inspection under the Arkansas Freedom of Information Act. The University of Arkansas at Little Rock is an affirmative action, equal opportunity employer and actively seeks the candidacy of minorities and women.

COLLECTION DEVELOPMENT LIBRARIAN/UNIVERSITY ARCHIVIST. Illinois Wesleyan University is embarking on academic program enhancements which will require expansion of library collections and is seeking a librarian who has the background and ability to assist with this development. Additional responsibilities include liaison with all Social Science and Business Departments, general reference, and maintenance of government documents. Tenure-track, $101 / 2$-month faculty appointment, rank open, to begin August 1,1990. Qualifications: MSLS from accredited library program, doctorate in an area of Social Sciences, including History, strongly preferred, ability to work with students and faculty and meet university requirements for tenure. Salary range $\$ 24,000-\$ 30,000$ depending on background and experience, excellent benefits. Illinois Wesleyan University is an equal opportunity employer and strongly affirms the need for applications from women and minorities. Send letter of application, resume, names, addresses, and telephone numbers of 3 references to: Clayton Highum, Illinois Wesleyan University Library, 201 E. University Street, Bloomington, Illinois 61702.

COLLECTION DEVELOPMENT/REFERENCE LIBRARIAN (Assistant Librarian). Responsibilities: Analyze and evaluate Library holdings, select materials in assigned subject areas, and serve as collection development liaison with the appropriate academic programs; provide reference desk service to library users; participate in the Library's bibliographic instruction program; and perform related duties. Qualifications: ALAaccredited MLS; demonstrated ability to communicate effectively orally and in writing; strong service orientation; demonstrated analytical skills; and a strong liberal arts background are required. Demonstrated ability to work cooperatively with others is essential. Preference will be given to applicants with training in online database searching and successful academic library reference experience. Knowledge of at least one modern foreign language and experience with microcomputer applications are desirable. Salary: Dependent on qualifications and experience. Minimum of $\$ 21,000$ per fiscal year. To apply: Send letter of application, resume, and the names, addresses, and telephone numbers of three references to: Betty Gauthier, Mardigian Library, The University of Michigan-Dearborn, Dearborn, MI 48128-1491. Review of applications will begin February 1, 1990; applications will be accepted until the position is filled. The University of Michigan-Dearborn is an equal opportunity employer and invites and encourages applications from women and minorities.

COLLECTION MANAGEMENT LIBRARIAN, Arts and Sciences Libraries, Tufts University. The University: Tufts University, founded in 1852, is an independent non-sectarian universityy of high quality, with about 8,318 students, providing degree programs at both undergraduate and graduate levels in liberal arts and professional areas. The faculty of Arts and Sciences offers baccalaureate programs in engineering, libera arts and sciences to almost 5,000 students. The faculty of Arts 
and Sciences also offers more than twenty master's level and doctoral programs in the arts and sciences and in engineering enrolling about 1,285 men and women. The Library: The Arts and Sciences Library, with basic resources in the humanities, socia sciences, biological and physical sciences has a collection of over 412,000 volumes, 310,000 government publications, 85,000 maps, 630,000 microform units, 9,200 sound recordings, ove 1000 films and videocassettes, and 2,333 current periodicals. The collections include the Government Publications and Map Room, Irene Eisenman Bernstein Audiovisual Center, Lufkin Engineering Library, Music Library, Rockwell Chemistry Library, Knipp Physics Reading Room, and Biology and Geology Reading Rooms. Data Research Associate's Atlas is the library's automated system. The Position: Position reports to Director of the Arts and Sciences Libraries. Tufts University seeks an individual with an ALA-accredited MLS or equivalent, to plan, create and direct collection development goals, policies and activities for all Arts and Sciences collections and subjects. The Collection Management Librarian will also coordinate collection plans with Health Sciences and Fletcher School of Law and Diplomacy libraries. Responsibilities: The position will be responsible for evaluating the libraries' collections, managing allocations of an acquisitions budget of more than $\$ 1$ million, coordinating the selection activities of faculty and librarians (including formalizing and directing the librarians' activities as departmental liaisons), and participating in the library management council. Qualifications: Excellent analytical, organizational and communication skills, with the ability to work effectively with faculty, department chairs, library managers, librarians and staff to negotiate allocations of acquisitions budget and staff time, and with the ability to take a leadership role in the library. Experience with budget process in an academic or research library; experience with database management and/or automated fund accounting. Familiarity with all library formats and an ability to evaluate their appropriateness. A broad knowledge of library operations and services and how they support university research and teaching goals. Experience in collection development or acquisitions preferred. Salary and Benefits: Appointment and salary commensurate with experience. 4 weeks vacation. Dental, medical (Blue Cross and HMOs), retirement (TIAA/CREF and others) and other benefits. To Apply: Please send letter, resume and names of three references to: Director, Arts and Sciences Library, Tufts University, Medford, MA 02155. Screening for this position will begin on February 15, 1990 , and will continue until filled. Tufts University is an affirmative action/equal opportunity employer and encourages applications from women, minorities, disabled persons and Vietnam era veterans.

COLLECTION MANAGEMENT LIBRARIAN. Position to be filled on March 1, 1990, reports to Coordinator of Collection Management and is responsible for supervising the selection, bibliographic searching, ordering, follow-up, and receipt of books and materials; maintaining continuation orders: and the handling of gifts and

\section{DIRECTOR OF LIBRARY}

\section{The Phillips Memorial Library, Providence College}

Applications and nominations are invited for the position of Director of the Phillips Memorial Library.

Providence College is a four-year college of the liberal arts and sciences with an undergraduate enrollment of approximately 3,600 men and women. It is conducted under the auspices of the Order of Preachers of the Province of St. Joseph, commonly known as the Dominicans. As a small Catholic undergraduate liberal arts college, Providence College has as its primary objective the intellectual development of its students in the disciplines of the sciences and the humanities within the atmosphere provided by the unique Catholic educational tradition of the Dominican Order. Founded in 1917, it is located on a rural campus within the urban boundaries of the City of Providence, Rhode Island, within 50 miles of Boston, Massachusetts and 150 miles of New York City.

The Director holds full faculty status and reports to the Associate Vice President for Academic Administration of the College. The Director is responsible for the administration and management of the Phillips Memorial Library, a facility of 111,513 square feet with holdings of 290,000 volumes. The Phillips Memorial Library's annual budget for academic year $1989-1990$ is $\$ 1,200,000$. The library has a full-time professional and clerical staff of 22, supplemented by a part-time staff of 19 .

Qualifications: master's degree from an ALA-accredited program plus substantial managerial experience in an academic/research library. Qualifications should also include at least three years experience in supervision and administration within an academic library setting. Because this is a faculty position, a Ph.D. is preferred. Expertise must be demonstrated in collection development, strategic planning, personnel and fiscal management, as well as facilities planning. Expertise in the field of information technology and library computerization is considered a particularly valuable asset.

This position will be available on July 1, 1990. Closing date for applications is March 1, 1990. Salary for the position is competitive (minimum $\$ 40,000$ ) and includes a substantial fringe benefit program. Applicants should forward their vitae with at least three telephone references to:

\section{James H. McGovern \\ Associate Vice President for Academic Administration \\ Providence College \\ Providence, RI 02918}

Providence College is an Affirmative Action, Equal Opportunity Employer. 
requests for out-of-print items. Acts as resource person to staff, interacts with faculty and booksellers, and plans and implements newly acquired PALS automated acquisitions system. Some rotated evening and weekend reference work is required. Required, ALA-accredited MLS degree and ability to work effectively with faculty, students, and library staff. Preferred: Experience with collection development and acquisitions procedures, OCLC or other bibliographic utility, and automated acquisitions system. This is a 12-month tenure-track appointment with academic rank and salary commensurate with qualifications. Application deadline is February 1, 1990. Generous benefits include full-paid State or TIAA/CREF retirement, 24 days annual leave, 12 days sick leave, and 11 paid holidays. Candidates should send an application letter, resume, and names, addresses and telephone numbers of three recent references to: J. Donald Craig, University Librarian, Middle Tennessee State University, Murfreesboro, TN 37132. MTSU is an equal opportunity, affirmative action employer; minorities and women are encouraged to apply.

COORDINATOR OF PUBLIC SERVICES, Ithaca College Library Direct, coordinate, and supervise operation and administration of

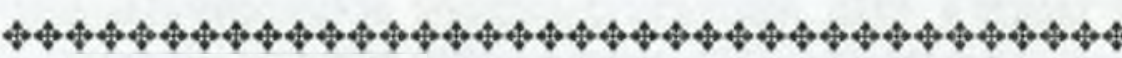

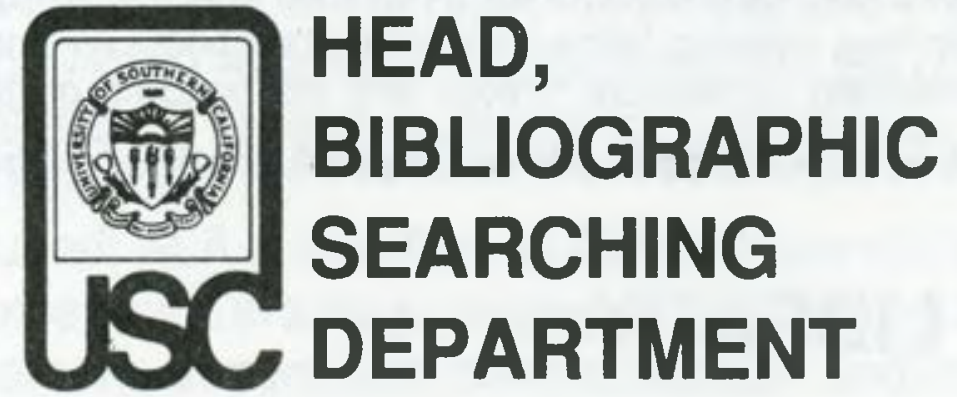

Doheny Memorial Library

Head, Bibliographic Searching Department, manages department's functions and staff. Responsible for coordinating departmental work flow with other departments in Division. Represents Bibliographic Searching Department in Department Heads meetings, and participates in ongoing planning for Division as a whole. Coordinates ordering priorities with selectors and the AUL for Collection Development. Works with the AULs for Technical Services and Collection Development on priority processing for various funds.

MLS/ALA, at least two years of technical services experience, cataloging or bibliographic searching preferred. Experience with automated technical services system, or subsystems, required.

Salary: Librarian I, \$28,900; Librarian II, $\$ 32,000$ minimum salary, plus benefits.

Position open: March 1, 1990, and will remain open until filled.

Apply to:

\section{Carolyn J. Henderson \\ Associate University Librarian \\ for Administrative Services \\ Doheny Memorial Library \\ University of Southern California \\ University Park \\ Los Angeles, CA 90089-0182}

Applicants submit a letter of application; resume; and names, addresses and telephone numbers of three references. Refer to Head, Bibliographic Searching Department, Position\#133CRL.

\section{AAVEOE.}

public services (reference, circulation, reserve, ILL, library instruction, database searching): be responsible for departmental management (planning, budget, staff development); integrate traditional and advanced library technologies with library's informational service; develop and maintain successful relationship with library users; participate as reference librarian (some evening and weekend work). Required: ALA-accredited MLS; demonstrated ability to create, evaluate, and coordinate public services; record of successful administrative experience in progressively responsible positions; demonstrated leadership qualities; excellent interpersonal as well as oral and written communication skills; reference experience. Helpful: knowledge of database searching; library instruction experience. Send letter of application, resume, and names, addresses and telephone numbers of three references to: W. Robert Woerner, Director of the Library, Ithaca College Library, Ithaca, NY 14850. Applications accepted until position is filled, review starts January 22, 1990; appointment effective as soon as possible thereafter. Ithaca College, located in the Finger Lakes region of upstate New York, is a comprehensive college enrolling approximately 6,400 students. The Library has 300,000 volumes, 2,200 periodical subscriptions, and 2,000 serials. An Affirmative Action, Equal Opportunity employer.

CURATOR, SOUTHEAST ASIAN COLLECTION. $\$ 30,000$ minimum. Twelve-month contract; tenure track. MLS from an ALA accredited library school required for appointment as instructor. For assistant professor or above, a second master's degree or 30 hours of graduate coursework (preferably in Southeast Asian studies), or equivalent, required in addition to MLS. Burmese and/ or Thai language ability preferred. Manages collection development, services, and personnel administration; coordinates technical processing for SEA collection. Provides leadership in develop-

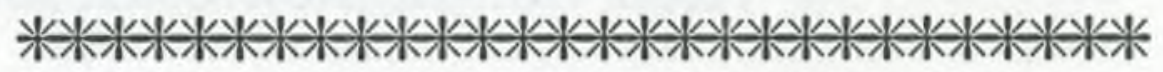

\section{FOUR POSITIONS}

\section{Northern Arizona University Flagstaff}

Applications are invited for the following professional positions at the Cline Library.

Readvertised positions are:

Acquisitions Librarian, $\$ 24,000$

Archivist and Manuscripts Curator, $\$ 24,000$

Serials Librarian, $\$ 24,000$

Library Software Specialist, $\$ 22,000$

12-month contract with academic professional status. Job descriptions are available upon request. Send letier of application, resume, and names and addresses of three references to:

\section{Jean D. Collins, University Librarian Northern Arizona University \\ Cline Library \\ P.O. Box 6022 \\ Flagstaff, AZ 86011 \\ Phone: (602) 523-6802}

Review of applications will begin December 15, 1989.

Northern Arizona University is an Equal Employment Opportunity, Affirmative Action employer, with the advancement of women and minorities as an institutional commitment.

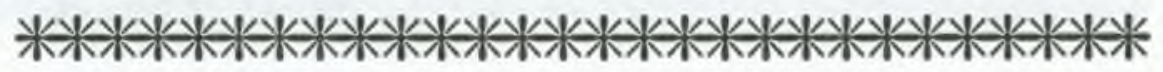




\title{
דיבוב THE MARTHA BOAZ DISTINGUISHED RESEARCH PROFESSORSHIP
}

\author{
The Central Library System of the University of Southern California
}

The Martha Boaz Distinguished Research Professorship is awarded annually to a distinguished member of the Library or Information Science profession to enhance strategic planning and applied research for the Library during a six-month period. The recipient for the 1990 calendar year will hold a visiting appointment to the University of Southern California's Central Library System and will work to develop a comprehensive library instruction program for the system. It is expected that this will include an analysis of the current program, identification of areas where development is needed and proposed staffing and costs. This program is being developed as a prototype for instruction in the Teaching Library which is projected to open in fall 1992. It will involve librarians throughout the 14 Specialized Subject Libraries the Central Library Services which include Reference, College Library, Access Services, and Government Documents, Technical Services, Academic Information Services and the Center for Scholarly Technology.

An award of $\$ 25,000$ and certain expenses related to the fellowship may be expected.

Qualifications: the Master of Library Science or Information Science degree; evidence of substantial accomplishment in library instruction in a large academic institution; and recognized standing in the profession.

Applications should be submitted to:

\author{
Dean Charles Ritcheson \\ University Librarian and Vice-Provost \\ Doheny Memorial Library \\ University of Southern California \\ University Park \\ Los Angeles, CA 90089-08182
}

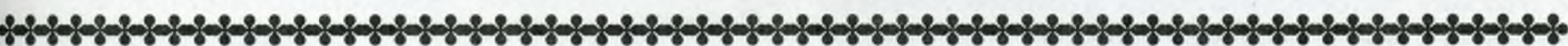

ing, interpreting and publicizing library services and collections. Send a statement of qualifications, resume, and names, addresses, and telephone numbers of three references by February 1, 1990 to: Gordon Rowley, Associate Director, University Libraries, Northern Illinois University, DeKalb, IL 60115.

DIRECTOR OF LIBRARIES. Washington State University invites applications and nominations for the position of director of libraries. The Director is the Chief Administrative and Financial Officer of the University Libraries and reports to the Provost. Washington State University is a comprehensive research institution which is the land-grant university for the State, with a student enrollment of 17,700 , including 2,000 graduale students. The Library system has a collection of approximately $1,600,000$ volumes, $2,540,000$ microform units, 302,000 audiovisual units, and a current subscription list of 32,000 serial titles. The current staff includes 45 faculty, 112 classified staff, and 52 FTE student assistants. The Library is a member of the Association of Research Libraries, the Center for Research Libraries, and the Western Library Network. Qualifications for the position include: an ALA-accredited MLS degree; demonstrated and substantial success as a leader in a research library; a strong commitment to excellence; managerial experience with library automation; and demonstrated ability to work effectively with people at all levels. Desirable qualifications include the doctoral degree and/or a second master's degree, successful experience in development and fundraising, and experience with centralized library services in a multi-campus setting. Nominations will be accepted until December 15, 1989. Screening of applicants will begin January 4, 1990, and will continue until the position is filled. Nominations or letters of application, accompanied by a vita and a list of at least four references should be sent to: Fredrick J. Dobney, Chair, Director of Libraries Search Committee, Vice Provost for Extended University Services Washington State University, Pullman, WA 991641041. Washington State University is an equal opportunity, affirmative action educator and employer. Members of ethnic minorities, women, Vietnam-era or disabled veterans, persons of disability, and/or persons between the ages of 40 and 70 are encouraged to apply.
DIRECTOR OF LIBRARY. Tenure-Track Faculty Position, Samuel Read Hall Library. Starting date: July 1, 1990. Salary \$26,000$\$ 29,000$ plus substantial benefits. Undergraduate college with 1,100 students located in Lyndonville in the northeast section of Vermont. Successful candidate will be responsible for overall management, including staff supervision (8) and budget, for a service-oriented academic library and will plan and coordinate development of diverse collection. Duties in the year-round position include some evening and weekend reference work and coordination of expansion of a DRA-automated system and development of other technologies. Library expansion planned in near future. Required qualifications include MLS from ALA-accredited program; 3 years library administrative experience; substantial familiarity with public and technical services automation, preferably Data Research Associates. Second advanced degree preferred. Send resume and letters of reference, by February 1, 1990, to: Perry Viles, Academic Dean, Lyndon State College, Lyndonville, VT 05851. Lyndon State College is proud of its tradition of providing personal and individual attention to students. Successful candidates for faculty, staff, or administrative positions are those who share in our commitment to students as our first priority. AAJEOE.

DOCUMENTS LIBRARIAN, LOCAL AND INTERNATIONAL. The Atkins Library of the University of North Carolina at Charlotte seeks an individual who, under the direction of the Documents Unit Head, will have the following responsibilities: Develop and maintain the local documents collection including establishing contacts with local government agencies; develop and maintain the international documents collection; provide documents and maps reference service; and teach students and faculty to use the library. The library is a selective depository for federal documents; a full depository for state documents; and a partial depository for local documents. Some night and weekend work is required. Library experience in documents preferred. Microcomputer experience preferred. Excellent public services skills required. Supervisory experience highly desirable. Well-developed organizational and communication skills a necessity. ALA-accredited master's degree required. Twelvemonth contract. Minimum salary $\$ 23,000$. State mandated benefits. Send resume and the names of three references by March 2, 1990, 
to Documents Search Committee c/o Carole Mclver, Administrative Services Librarian, Atkins Library, The University of North Carolina at Charlotte, Charlotte, NC 28223. AAEEO.

GOVERNMENT PUBLICATIONS LIBRARIAN. Entry level, $\$ 22,000$ minimum. Twelve-month contract; tenure track. MLS from an ALA-accredited library school required for appointment as Instructor. For assistant professor or above, a second master's degree or 30 hours of graduate coursework, or equivalent, required in addition to MLS. Interest in working with the international collections in Government Publications. Participates in collection development, reference desk service, library instruction, technical processing, online database searching, and planning and policy development. Send a statement of qualifications, resume, and names, addresses, and telephone numbers of three references by February 1, 1990, to: Elizabeth Titus, Assistant Director, University Libraries, Northern Illinois University, DeKalb, IL 60115.

HEAD, BIOMEDICAL INFORMATION SERVICES. The University of New Mexico Medical Center Library seeks candidates for a supervisory position strong in program development and responsible for reference, online and user instruction and information services in multi-program Academic Health Sciences Center. The library serves the Schools of Medicine, Nursing, Pharmacy, Allied Health, and Dental Programs, the UNM Hospital, Children's Psychiatric Hospital, Mental Health Center, Cancer Research and Treatment Center, and all patient care clinics of the medical center. The library also conducts an extensive educational program, a multi-faceted statewide outreach program, and serves as resource library in the Talon Region. The library has a full-time staff of forty-two, a collection exceeding 150,000, over 2,000 current subscriptions, a large media center, and a New Mexico medical history and archives collection. The library has at online, statewide public access catalog. Required: MLS from an ALAaccredited school, MLA certification desirable. Minimum five years professional experience in medical reference work, online instruction and searching, and supervision or project management; must be a good team player, possess leadership, oral, and written communication skills. Minimum salary $\$ 32,500$ depending on experience. Non-probationary faculty appointment. Send letter of application, resume, salary requirements, and three references to: Search Committee, University of New Mexico, Medical Center Library, Albuquerque, NM 87131.

EOE/AA employer.

HEAD CENTRAL REFERENCE LIBRARIAN. The University of Arizona is seeking a librarian to manage the Central Reference Department which provides information service in the social sciences, humanities, and fine arts. Responsibilities include managing a department with 12 librarians, 9 career staff, and 3 FTE student assistants and overseeing reference service, computerized reference services, specialized library instruction, collection development, and interlibrary loan. The head works closely with other departments in the library system, serves on library-wide administrative committees, and is one of six department heads who report to the Assistant University Librarian for Central Services. The University of Arizona Library has an aggressive Affirmative Action plan. Women and minorities are encouraged to apply. Applicants must have a Master's degree in Library Science from an ALA-accredited school and at least five years of professional library experience in an academic, research or comparable library with demonstrated supervisory, planning, and leadership skills. Experience with reference service is required, and familiarity with library instruction, computerized reference services, collection development, and interlibrary loan is preferred. A commitment to responsive and innovative library services is required as are strong written and oral communication skills. Preference will be given to candidates with academic backgrounds in the social sciences, humanities, or fine arts. Minimum salary is $\$ 32,000$, or higher depending upon qualifications and experience. Librarians at the University of Arizona have academic professional status, are eligible for continuing status, are voting members of the faculty and may take up to 24 days professional leave per year. They have 12 -month appointments with 22 days vacation, 12 days sick leave and 10 holidays. Send letter of application, resume, and the names of three referees to: W. David Laird, University Librarian, University of Arizona Library, P.O. Box C, Tucson, AZ 85721. Review of applications will begin February 28, 1990; however, applications will be accepted until the position is filled. The University of Arizona is an Equal Employment Opportunity employer with an Affirmative Action plan. All persons hired will be required to show proof of their identity and right to work in the United States.

HEAD, DOCUMENTS PROCESSING, Washington State University Libraries (position readvertised). Coordinates the work of the Documents Section in the Bibliographic Control Unit of the Technical Services Division. Catalogs document serials and mono graphs, and assigns classification numbers to copy cataloging Responsible for reviewing processing of surveys for U.S. depository documents, claims processing and receipt, Washington State Depository shipments. Serves as liaison with Public Service units for depository issues. Chairs library-wide Government Documents

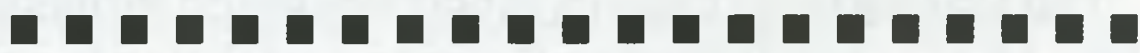

\section{ASSISTANT DIRECTOR FOR PUBLIC SERVICES}

\section{University of Michigan, Ann Arbor}

Duties: Responsible for the direction of public services activities for 31 service units with 7 department heads reporting directly. Incumbent is responsible for policy development, evaluation of and planning for public services, divisional communication and supervision, faculty relations, resource allocation and personnel actions, and other administrative and professional activities which maintain and enhance the provision of library services to the University community. Participates in administrative decision-making for the library organization as a whole. Reports to the deputy director and is a member of Cabinet.

Qualifications: Substantial managerial and administrative experience in a research or an academic library with an emphasis on public services. Demonstrated success in written and oral communication, analytical, budgeting and planning activities. Knowledge and understanding of research library organization and interrelationship of divisions, and sound grasp of issues and trends facing research libraries. Knowledge of and experience with library automation. Ability to work in a group context. Proven leadership ability with staff and in the profession. Master's degree in Library Science from an ALA-accredited library school.

Salary and leave: Minimum salary of $\$ 65,000 ; 24$ working days of vacation a year; 15 days of sick leave a year with provisions for extended benefit.

Retirement plan: TIAA/CREF Retirement Plan.

Apply to:

Lucy R. Cohen, Manager
Library Personnel Office
404 Hatcher Graduate Library
University of Michigan
Ann Arbor, Ml 48109-1205

Application deadline: applications received by January 30, 1990 will be given first consideration.

The University of Michigan is an non-discriminatory, affirmative action employer 


\section{Senior Associate University Librarian}

Boston College Libraries seeks applications and nominations for a newly defined position of Senior Associate University Librarian. Working closely with the University Librarian, this position will be responsible for the internal operations of the University Libraries. Specific responsibilities include: coordinating the effective organization and delivery of all library services to the university community through three AULs with responsibility for collections, access and technical services; planning and policy formulation for the Libraries, including performance measurement; chairing the Library Administrative Group; library facilities; grantsmanship; and library public relations. Together with other library staff, the Senior Associate will design and implement innovative programs to enhance the Library's role in the intellectual life of the University.

Boston College, a coeducational Jesuit university of 9,000 undergraduates and 5,500 graduate and professional students, is committed to the ideal of excellence and service to others. Boston College Libraries are recognized as the focal point for research and information services at the university. The Libraries have a combined staff of over 50 professionals, 90 support positions and 200 student assistants, with holdings of over 1.1 million printed volumes and an annual budget approaching $\$ 8$ million. Fully automated since 1984 , the Libraries have recently migrated to the NOTIS system and continue to be leaders in using information technology to expand services. The Library administration encourages open communication, creativity, and staff development at all levels of the organization.

The successful candidate will be an ALA-accredited MLS with 10 years academic or research library experience combining front-line work with increasing

management and supervisory responsibilities. Strong interpersonal skills and a commitment to collegial, flexible management is essential, as is the ability to manage change and maintain stability in a dynamic, fastpaced environment. A background in collection development, budget and personnel management processes is desirable. Evidence of active participation in the library profession, with excellent writing and oral presentation skills are also required.

Our comprehensive benefits include 22 days vacation; tuition remission for employee, spouse and children; a wide range of insurance programs; use of recreational and university facilities and the availability of an on-site child care center. Salary from $\$ 48,000$ depending on qualifications. Applications received by March 1, 1990 will receive first consideration. Apply to:

Dr. Mary J. Cronin, University Librarian, $\mathrm{O}^{\prime} \mathrm{Neill} 414$, Boston College, Chestnut Hill, MA 02167.

An Equal Opportunity/Affirmative Action Employer.

\section{BOSTON COLLEGE}


committee (GoDoC). Required: ALA-accredited MLS or its foreign equivalent; experience in processing state and federal depository receipts; cataloging experience, preferably of government documents; demonstrated knowledge of SuDocs classification, LCSH, AACR2, and other cataloging tools. Preferred: Experience in an academic or research library; supervisory experience; experience in MARC tagging, bibliographic utilities, preferably WLN; demonstrated verbal and written communication skills. Salary: From $\$ 25,000$. Rank: Librarian 2 or 3 , commensurate with qualifications and experience; full faculty status. Benefits: TIAACREF; broad insurance program, 22 days vacation, 12 days/year sick leave. Application procedures: Send letter of application, resume, and names of three references to: Donna L. McCool, Associate Director for Administrative Services, Washington State University Libraries, Pullman, WA 99164-5610. Application review begins: February 1,1990 . Washington State University is an equal opportunity affirmative action educator and employer. Members of ethnic minorities, women, Vietnam era or disabled veterans, persons of disability, and/or persons between the ages of 40-70 are encouraged to apply.

HEAD, HUMANITIES COLLECTION DEVELOPMENT, Washington State University Libraries. Supervises all aspects of Humanities collection development and management for the WSU Libraries. Selects materials for purchase in English and American literature. Works closely with teaching faculty and other subject specialists in the Humanities. Provides full range of general reference services in all Humanities and Social Science disciplines Participates in library user education program. Works cooperatively with other heads of collection development to deal effectively with issues of mutual concern. Serves on the Libraries' Collection Development Committee. Reports to the Head, Humanities/Socia Sciences Libraries. Required: ALA accredited MLS; Masters or above degree in English or American literature or American Studies with emphasis on literature. Experience as collection manager subject bibliographer or in acquisitions in an academic/research

\section{ASSISTANT DIRECTOR FOR COLLECTIONS}

\section{lowa State University}

The Assistant Director, working within a team of four other Asssistant Directors and reporting to the Dean, shares broad responsibility for management of the Library system. Primary responsibility involves all aspects of collection development and management including: developing the Library's research collections in support of the University's programs; coordinating the preparation of collection development policies; allocating and monitoring acquisitions funds of over $\$ 3.3$ million; working with the Dean and the University Development Office on fundraising and donor relations; directing collection management activities of the bibliographers and selectors; and overseeing three units: Collection Development, Collection Preservation and Conservation, and Special Collections and University Archives. The Division includes 7 professionals and 6 FTE support staff. In addition, 8 librarians outside the Division participate in selection and collection management activities in specialized areas.

Required: MLS from an ALA-accredited school required, advanced degree in a subject field strongly preferred; a minimum of 5 years collection development experience in a major academic library, knowledge of major issues in collection development and preservation; demonstrated planning, fiscal, and analytical skills; ability to communicate effectively and manage successfully; appreciation of the scholarly use of collections; ability to maintain effective working relationships with the University community; understanding of the application of automation to library operations; ability to view issues from a broad Library-wide perspective, ability to meet promotion and tenure requirements.

Salary and Benefits: $\$ 45,000$ minimum, competitive benefits.

lowa State offers a positive environment for career growth and challenge. Situated on a beautiful campus, the recently remodeled and expanded Library actively serves a community of over 25,000 students and supports nationally recognized collections in excess of 1.7 million volumes, 2 million microforms and 21,000 current serial subscriptions. Special Collections and University Archives has strong collections in agriculture and natural science as well as a rich documentation of historical records and the American Archives of the Factual Film. A fully integrated Library system is being installed (NOTIS). The Library is a member of ARL, CRL, BCR, and OCLC. Ames is a community of 50,000 located 35 miles from Des Moines, the state capital. The city supports quality schools and outstanding cultural attractions.

Application: Review of applications will begin February 9, 1990. Submit letter, resume, and the names, addresses, and telephone numbers of three references to:

\section{William K. Black \\ Assistant Director for Administrative Services and Personnel lowa State University \\ 302 Parks Library \\ Ames, IA 50011-2140 \\ Telephone:(515) 294-1442}

lowa State University has a strong commitment to equal opportunity and affirmative action. Members of protected classes are especially encouraged to apply. 
library. Reference experience in an academic/research library. Preferred: Reading knowledge of a modern foreign language; reference experience in the Social Sciences; experience with user education and automated systems. Salary: From \$30,000; commensurate with qualifications and experience. Rank: Librarian rank commensurate with qualifications and experience; full faculty status. Application procedure: Send letter of application, resume, and names of three references to: Donna L. McCool, Associate Director for Administrative Services, Washington State University Libraries, Pullman, WA 99164-5610. Application review begins January 31, 1990. Washington State University is an equal opportunity, affirmative action educator and employer. Members of ethnic minorities women, Vietnam era or disabled veterans, persons of disability, and/or persons between the ages of 40-70 are encouraged to apply.

HEAD, HUMANITIES/SOCIAL SCIENCES LIBRARIES, Washington State University Libraries. Responsible for the administration of the Humanities and Social Sciences collections and services in Holland Library and the branch education Library and branch Architecture Library. Areas and services include reference, collection development, circulation, database searching, interlibrary loans, user education, microform collection and serial records. May participate in collection development and reference. Present staff includes 12.5 FTE librarians, 27.65 FTE classified staff, and 16.3 FTE student assistants. Conducts annual review evaluations of library faculty and relevant classified staff in the division. Works cooperatively with heads of other divisions in the Libraries to deal effectively with issues of mutual concern. Reports to the Director of Libraries and serves on the Director's Council, the advisory body of principal administrators. Required: ALA accredited MLS; substantial demonstrated successful experience, including some administration in a sizable public service area of an academic or large public library. Undergraduate degree in the Social Sciences or Humanities. Applicants should have a strong service commitment, an understanding of research needs, experience in planning and implementing change, demonstrated leadership, outstanding communication skills, and the ability to handle a variety of situations with patience, tact, and fairness. Preferred: Additional graduate degree in Social Sciences or Humanities; experience with database searching, automated systems, user education, building construction and renovation and academic curriculum reform. Salary: From $\$ 35,000$; commensurate with qualifications and experience. Rank: Librarian rank commensurate with qualifications and experience; full faculty status. Benefits: TIAACREF, broad insurance program, 22 days vacation, 12 days/ year sick leave. Application procedures: Send letter of application, resume, and names of three references to: Donna L. McCool, Associate Director for Administrative Services, Washington State University Libraries, Pullman, WA 99164-5610. Application review begins: January 31, 1990. Washington State University is an equal opportunity, affirmative action educator and employer. Members of ethnic minorities, women, Vietnam era or disabled veterans, persons of disability, and/or persons between the ages of 40-70 are encouraged to apply.

HEAD, HUMANITIES/SOCIAL SCIENCES REFERENCE (position readvertised). Permanent 12-month position. Under the direction of the Head, Humanities/Social Sciences Libraries and in consultation with divisional library faculty, plans, implements, and administers the programs and services for the Humanities/Social Sciences reference unit. Assesses user needs. Develops shortand long-range plans, including planning for the department for an addition to the library building and the resulting move of reference services. Responsible for scheduling reference desk hours. Develops and manages the Holland Library reference collection. Prepares unit budget requests and monitors budget allocations. Plans for the collection of statistics and prepares analytical reports. Shares supervision of unit classified staff with collection development coordinators. Provides direct reference service to patrons. Participates in the Libraries' user education program. Performs collection development and liaison activities in assigned subject areas. Required: ALA-accredited MLS or its foreign equivalent; substantial professional reference experience in the humanities and social sciences in an academic library, including managerial responsibilities; proven interpersonal relations and communication skills. Demonstrated evidence of leadership. Preferred: Online search services experience; experience in the application of microcomputer and other technologies to reference services, including CD-ROMs. Experience in library user education; reference experi- ence in business, documents or law. Salary: $\$ 30,000$ minimum. Salary at appointment will be commensurate with qualifications and experience. Rank: Librarian 2 or 3; tenure-track status. Benefits: TIAACREF; broad insurance program, 22 days vacation, 12 days/year sick leave. Application: Send letter of application, resume, and names of three references to: Donna L. McCool, Associate Director for Administrative Services, Washington State University Libraries, Pullman, WA 99164-5610. Applications must be postmarked by: February 15, 1990. Washington State University is an equal opportunity, affirmative action educator and employer. Members of ethnic minorities, women, Vietnam era or disabled veterans, persons of disability, and/or persons between the ages 40 to 70 are encouraged to apply.

HEAD, LIBRARY PERSONNEL SERVICES. The University of Maryland College Park Libraries invites nominations and applications for the following position: Head, Library Personnel Services, Librarian II, McKeldin Library, Administrative Services. Associate Staff, Full-time, 12-month appointment. Salary: $\$ 32,661-\$ 45,605$, commensurate with experience. Responsibilities: Responsible for all facets of the personnel operation for the University of Maryland

\section{REFERENCE
LIBRARIAN
Wellesley College}

Wellesley College invites applications for a new entry-level position as Reference Librarian at the Clapp Library. The library system is completely automated and is a member of the Boston Library Consortium of academic and research libraries.

Responsibilities: Serve at reference desk, develop and deliver bibliographic instruction lectures, perform online searches, select materials for the collections, assist in collection managemeni projects, supervise maintenance of microtext area. Some weekend assignments. REQUIRED: MLS from an ALA accredited institution; educational background in Humanities or Social Sciences; strong communications skills. PREFERRED: Experience with government documents, collections management, computerized literature searching, bibliographic instruction; 1-2 years' work in an academic library.

Screening of applications will begin in January 1990 and continue until the position is filled. Early submissions will receive special consideration. A letter of application, resume and names of 3 references should be directed to: Search Committee-Reference Librarian, Personnel Office, Wellesley College, Wellesley, MA 02181.

WELLESLEY COLLEGE IS AN EQUAL OPPORTUNITYI

AFFIRMATIVE ACTION EMPLOYER.

Wellesley College 


\section{The Philip Hofer Curator of Printing and Graphic Arts}

\section{The Houghton Library Harvard University}

Reporting directly to the Librarian of the Houghton Library (the major repository of rare books and manuscripts in Harvard College), the Hofer Curator is responsible for providing imaginative leadership for America's pre-eminent department of graphic arts and the history of printing. The collection comprises illustrated books, print portfolios, drawings for book illustration, fine printing and type specimens (all covering a period of five centuries) as well as illuminated and calligraphic manuscripts covering eight centuries. The curator bears primary responsibility for the development and conservation of the collection, and for acquisitions, fundraising, scholarship, teaching, exhibitions, and publications based on the collection.

Qualifications: An advanced degree in an academic discipline related to the holdings of the collection; successful experience within a special collections library, museum, or comparable institution; distinction in one's scholarly work; the ability to supervise department members and to perform other administrative tasks; and the ability to work in concert with colleagues in other departments to further the educational mission of the Library as a whole.

The Search Committee will begin screening applications on 1 December 1989 and will continue until this endowed curatorship is filled. To apply, please send a letter of interest, a resume, and the names of three referees to: Richard Wendorf, Librarian, The Houghton Library, Harvard University, Cambridge, MA 02138. An affirmative action/equal opportunity employer.

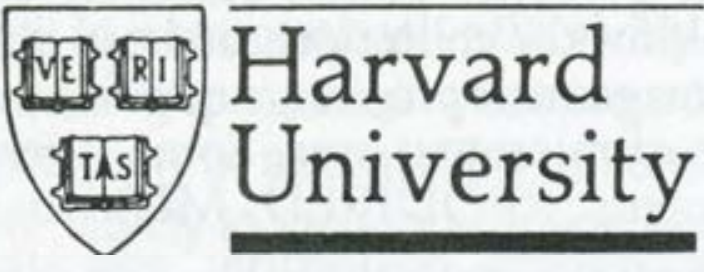

at College Park Libraries, including: Employment, Classification, Employee Relations, Staff Development, and Compensation. The UMCP Libraries employs 245 FTE. Develops and administers personnel policies and procedures for the Libraries within the framework of University policy. Qualifications: Required: MLS from an ALA-accredited program. Ability to communicate effectively in oral and written form. Proven managerial ability; analytical skills and organizational ability. Experience: Minimum of four years professional experience in large libraries, preferably several years in a supervisory capacity. Working knowledge of the principles and practices of personnel management. Benefits: 22 working days annual leave; 14 paid holidays; 15 days sick leave; University contributions to hospitalization, major medical insurance, and retirement (State pension system or TIAACREF); tuition remission for self and dependents. Position available immediately. Applications: For full consideration, submit resume and names/addresses of 3 references by February 28, 1990, to: Ms. Lupe Fernandes, Library Personnel Office, McKeldin Library, University of Maryland, College Park, MD 20742-7011. The University of Maryland is an affirmative action, equal opportunity employer.

HEAD OF ACCESS SERVICES. The University of Missouri-Columbia Libraries is seeking qualified applicants for the position of Head of Access Services. Principal responsibilities include the administration planning, goalsetting, and evaluation of the Access Services Division, which includes administration of effective circulation services, interlibrary loan, a current periodicals reading room, reserves, bookstack maintenance, and three off-site storage facilities. Participates with library administration and other division heads in policy decisions as a member of the Library Council. Serves as the liaison with the Library Systems Office for circulation functions, and acts as information source for other circulation units in the branch libraries. Reports to the Director of Libraries and is responsible for all personnel activities of the division, which includes one librarian and 23 clerical assistants. Requires minimum of a master's degree from an ALA-accredited program; three years experience in an academic (preferably research) library, including proven supervisory experience; a working knowledge of automated library systems, effective oral and written communications skills; and demonstrated ability to work effectively with faculty, students, and staff. Minimum salary: $\$ 25,000-\$ 30,000$ for 12 months commensurate with experience. Benefits include 30 vacation days per year, vested retirement after 5 years, dental insurance, and other normal fringe benefits, including $75 \%$ tuition waiver. Columbia is in the middle of the state on 1-70, only 2 hours from St. Louis and Kansas City, and 1.5 hours from the Lake of the Ozarks major recreational area. The University and two other colleges provide superb cultural events. According to the ACCRA composite index, the cost of living in Columbia is very reasonable when compared with other university communities. Available: March 1, 1990. Send letter of application, names of three references, and resume to Pat Burbridge, Personnel Coordinator, 104 (CN) Ellis Library, University of Missouri- Columbia, Columbia, MO 65201-5149. Applications received by January 15, 1990, will receive first consideration. The University of Missouri-Columbia is an equal opportunity/affirmative action employer and employs only U.S. citizens and lawfully authorized alien workers.

HEAD, REFERENCE DEPARTMENT, University of New Hampshire Library. Responsible for management of reference interlibrary loan services, bibliographic instruction, online database services, development of reference collection, establishment of a communications program to publicize reference services throughout university community, \& for planning, developing \& evaluating new programs \& services in support of library's goals. Directs \& evaluates work of 3 FTE librarians, 2 support staff \& student assistants. Participates in general management of library \& reports to University Librarian. This is a tenure-track faculty position appointment at the rank of assistant or associate professor dependent on experience \& qualifications. Library faculty expected to meet University promotion \& tenure requirements. Qualifications include an MLS from an ALA-accredited program, at least 5 years of professional experience in reference services in academic or research library, successful supervisory experience, strong interpersonal, communication \& problem-solving skills. Knowledge of \& experience with new technologies, record of publication \& professional activity. Preferred qualifications include a second graduate degree, experience with database searching \& bibliographic instruction, knowledge of collection development practices \& planning \& management of information technologies as they impact traditional reference services, reading knowledge of one foreign language. Minimum salary, $\$ 34,000$. Review of applications to begin January 10,1990 . Send resume \& names, addresses \& telephone numbers of three references (non-citizens must include current visa status) to: Ruth M. Katz, University Librarian, University of New Hampshire, Durham, NH 038243592. Women and minorities are encouraged to apply. UNH is an AA/EEO Employer.

HEAD, TECHNICAL SERVICES DEPARTMENT. To supervise cataloging, acquisitions, collection development, and serials. Qualifications: ALA-accredited MLS, 3 years of experience, preferably in an academic library, knowledge of OCLC and automated acquisitions desired. Evidence of managerial responsibility, with demonstrated planning, leadership, communication, and interpersonal skills required. Tenure-track faculty appointment on 12 month basis with 20 days annual leave and competitive standard benefits with $\$ 26,000$ minimum salary. Applications accepted until position is filled. Send letter, resume, and names, addresses and telephone numbers of three references to: Dean of the Library, Auburn University at Montgomery, Montgomery, AL 36117 3596. EEO/AA employer.

LIBRARIAN, entry-level. Assignments include reference, bibliographic instruction, database searching, collection development, and cataloging. ALA-accredited MLS and library automation experience or course work required. Starting salary $\$ 30,240+$. Start 


\title{
HEAD, MAIN LIBRARY REFERENCE DEPARTMENT AND COORDINATOR SYSTEM-WIDE REFERENCE SERVICES
}

\author{
The University of lowa Libraries, lowa City
}

Position Description: This is a senior leadership position responsible for the provision of reference and information services in the University of lowa Libraries system. The incumbent will manage resources of the Main Library's Reference Department, to include collections and services related to reference and information desk service, database searching, and an active program of user education activities. The staff consists of 8 librarians and 5.5 FTE assistants. The incumbent will Provide system-wide leadership and coordination in planning and implementing strategies to enhance services and collections, and in ensuring creative use of electronic technology in the provision of services. S/he will chair the Libraries' Reference Services Committee, a committee with representatives from all divisions within the system, and will serve on the Libraries' Administrative Council, a senior level advisory group to the university librarian. The incumbent will report to the assistant university librarian for reader services.

The Reference Department: Within the past two years staff have established separate reference and information service desks, have integrated the Libraries' online catalog and compact disc services into routines, and have developed a preliminary model reference statement to guide the future of the department. A major thrust has been undertaken in providing structure and direction to a growing user education program in which all librarians participate. The professional staff are engaged in collection selection activities in subject areas beyond the reference collection. In addition to department planning, staff have been engaged also in system-wide strategic planning.

The UI Libraries: The UI library system consists of the Main Library (collections/services relating principally to the social sciences/humanities) and 11 departmental libraries (art, music, business, and the sciences, including the health sciences). The University is a member of the Research Libraries Group (1979), and staff are actively engaged in national efforts.

The University and lowa City: A major research and teaching institution, the University of lowa offers nationally recognized programs in medicine and human biology, creative writing, law, and the fine arts. A faculty of some 1,600 serves 29,000 students. lowa City is a community with excellent educational, recreational, and cultural advantages and is readily accessible via interstate highways and a major airport 30 minutes distant.

Qualifications: The successful candidate will have a graduate library degree from an ALA-accredited program or the eguivalent; substantial management experience with professional staff in a research library; strong leadership abilities; and superior oral and written communication skills. S/he will have the ability to lead a major, key library unit in a positive, effective manner, will have significant experience in the provision of reference and information services to include user education, in a research library, and will be fully cognizant of the issues and technology related to the provision of excellent service. The successful candidate will be actively and productively engaged at a national level in professional activities pertaining to research library services, and will demonstrate a personal commitment to affirmative action and equal employment opportunities. Women and minority candidates are particularly encouraged to apply for this position. Appointment is to be made at either the Librarian III or IV level (equivalent to associate and full Professor ranks), at a salary expected to be in the range of $\$ 40,000$ to $\$ 45,000$ per annum. Comprehensive fringe benefits are offered, including TIAA/CREF and 25 days of vacation leave annually. It is anticipated that appointment to this position will be made no later than 1 July 1990.

Application Procedure: Screening of applicants will begin immediately and will continue until the position is filled. Applications received by February 1, 1990 will receive first consideration. Qualified individuals should submit a letter of application, vita information, and the names, addresses, and telephone numbers of three references to:

\author{
Barbara I. Dewey, Personnel Services \\ The University of lowa Libraries \\ lowa City, IA 52242 \\ Telephone: (319) 335-5867
}

The University of lowa is an Equal Opportunity, Affirmative Action Employer. 
June, 1990. Submit cover letter, resume, and the names, addresses, and phone numbers of 3 references postmarked by 2/9/90 to library Search Committee, California State University Library, 9001 Stockdale Hwy., Bakersfield, CA 93311-1099. CSUB is an AA/EOE.

LIBRARIAN. Liberal arts college library seeks a generalist eager for an unusual professional experience. Dickinson College has available a two-year renewable appointment for a librarian who would like to: become part of a team of nine librarians and fifteen support staff committed to both library services and education within the context of the liberal arts; share responsibilities and decisions with the other librarians; administer one or more areas of library operations; work closely with students and faculty; contribute to Technical Services as well as Public Services in an online environment. Responsibilities include cataloging; participation in the college's innovative Freshman Seminar program; serving as library liaison to provide bibliographic instruction and assistance in collection development for several academic departments. Excellent benefits include: support for professional research and development; 4 weeks vacation plus 4 weeks professional leave; status as academic professional entitles individual to sabbatical leaves and full participation in the governance of the college; tuition remission for family; TIAACCREF. Qualifications: ALA-accredited MLS and second master's in the liberal arts required; working knowledge of one or more foreign languages; familiarity with AACR2, Dewey classification, OCLC, and database searching desired. Minimum salary: $\$ 27,000$. Available July 1, 1990. Closing date February 20, 1990. Send letter of application, vitae, and three letters of recommendation to: Ella Forsyth, Chair, Department of Library Resources, Dickinson College, Carlisle, PA 17013. An affirmative action, equal opportunity employer.

LIBRARIAN to supervise University Library at Glasgow, Kentucky Responsible for management of new off-campus library located 30 miles from the main campus. Duties include reference, library instruction, and collection development for primarily undergraduate programs. Faculty position in the Department of Library Public Services reporting to the Circulation Services Supervisor. ALA accredited MLS required; excellent writing and verbal communica- tion skills; strong public service attitude. Flexible hours. Minimum salary $\$ 20,000$. Send letter of application, vita, and names and telephone numbers of three references to Office of Academic Affairs, Glasgow Campus Librarian Search, Western Kentucky University, Bowling Green, KY 42101. Review of applications wil begin February 1, 1990, and position will remain open until filled. Women and minorities are encouraged to apply. An affirmative action, equal opportunity employer.

LIBRARY DIRECTOR, St. Olaf College, Northfield, Minnesota. ALA-accredited MLS required; second master's degree or Ph.D. desirable. Experience with private undergraduate liberal arts college libraries and bibliographic instruction important. Extensive academic library experience including personnel development long-range planning and budgeting, library technology and automation, and cooperative networks required. Must possess effective communication skills, be committed to leadership in a collegial environment, and be willing to promote library visibility in the College community. The Library consists of the main library and two branch libraries (science and music) as well as the College Archives. It holds over 345,000 cataloged volumes, 36,000 bound periodical volumes (1,650 periodical subscriptions), and is a U.S. government depository. The Library is a member of the MINITEX OCLC and PALS networks, and has implemented an online cata$\log$ and acquisitions subsystem, with plans for a fully-automated integrated system within the next five years. A very strong program of course-integrated bibliographic instruction is in place. In addition to the director there are 10.5 FTE librarians with faculty status, a staff of 12.5 FTEs, and approximately 100 part-time student workers. The Library Director will have an eleven-month contract with faculty status and responsibilities; tenure at the Associate or full Professor rank. The Director reports to the Dean of the College. St Olaf College is a college of the Evangelical Lutheran Church in America. Entrance requirements are very competitive; a student body of 3,000 and a faculty of 382 (225 full time). Located 45 miles south of the Minneapolis/St. Paul city centers, 20 miles from the edge of the Minneapolis/St. Paul suburbs, in a picturesque small town. Application deadline is March 16, 1990. Applications and nominations should be sent to: Jon Moline, Vice-President and Dean of the College, St. Olaf College, Northfield, MN 55057.

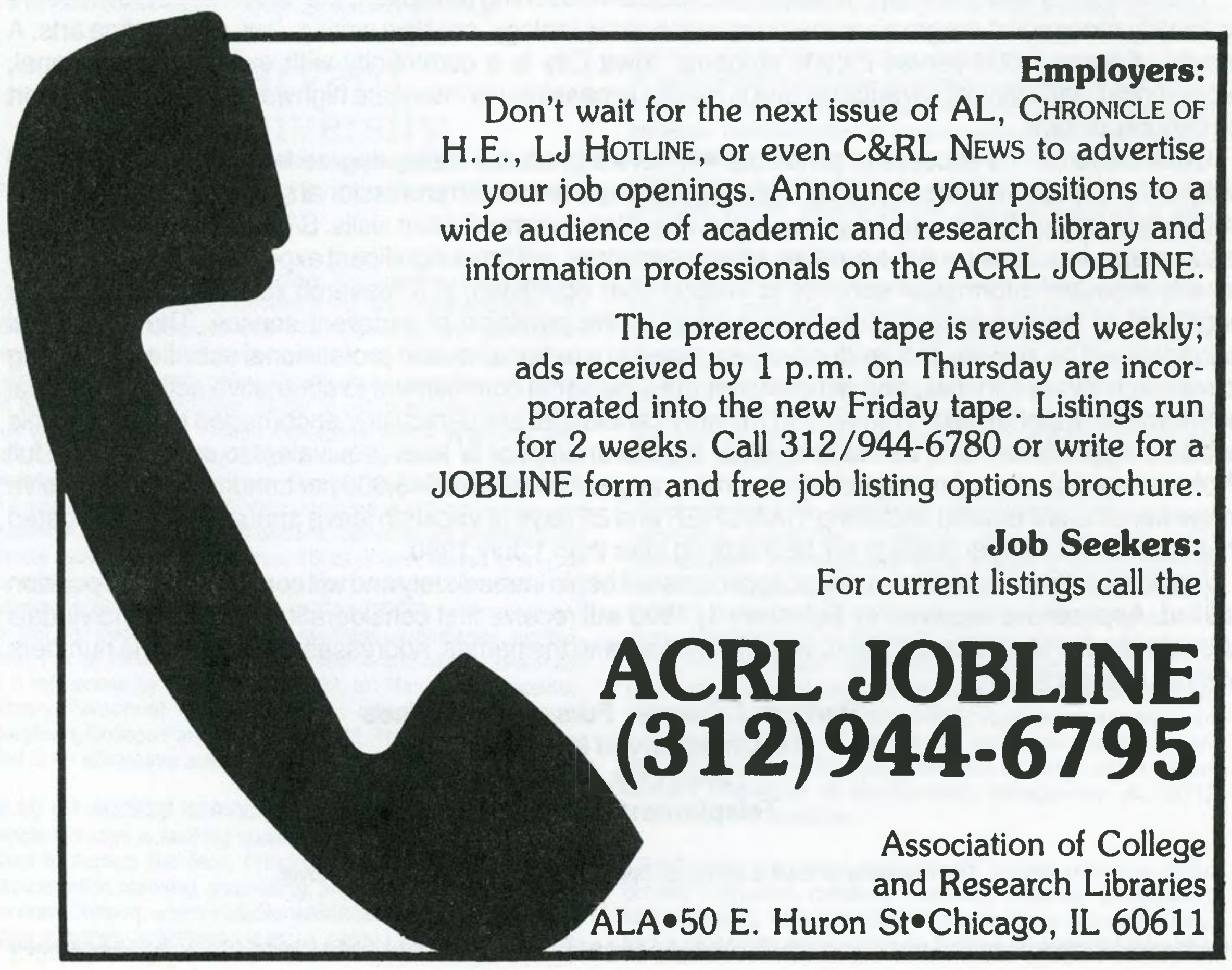


PERSONNEL LIBRARIAN, Arizona State University. Provides detailed support for the recruitment, selection, training, development, discipline and evaluation of all library personnel. Responsibilities include the promotion of affirmative action and equal opportunity; assistance with a wide variety of personnel actions; creation and implementation of staff development programs; participation in strategic planning; and cooperative involvement in a host of related activities. ASU, a progressive library offering significant potential for personal growth and development, is staffed by 82 FTE professionals, 182 FTE classified staff, and 50 FTE student assistants. Required: ALA-accredited MLS degree; exceptional communication and interpersonal skills, including demonstrated writing, listening and public speaking ability; management, organization and analytic skills; understanding of and commitment to the principles of affirmative action and equal employment opportunity; two years' post-MLS experience in a large library system; supervisory ability; demonstrated interest in professional development and service involvement. Preferred: Supervisory experience in a large academic library; academic training and/or experience in personnel; record of professional achievement. Salary: $\$ 25,000$ and up, dependent on qualifications and experience. To apply: Send letter of application, resume, and the names, addresses and telephone numbers of four recent references to Constance Corey, Associate Dean of Libraries, Hayden Library, Arizona State University, Tempe, AZ 85287-1006. Telephone: (602)965-3417. Application deadline: January 31, 1990, and the last day of each month thereafter until the position is filled. ASU is an affirmative action, equal-opportunity employer.
PUBLIC SERVICES LIBRARIAN, Assistant Professor (tenuretrack, 12-month position, available July 1, 1990). Dakota State University is seeking an energetic, service-oriented individual to join a team of forward-looking, dedicated librarians and associates. The University's mission emphasizes the use and integration of computer technology in all aspects of its curriculum. This unique approach has been recognized nationally and provides an exciting and innovative atmosphere for students, faculty, and staff. The Karl E. Mundt Library was the first library in South Dakota to add CDROM technology. Plans call for CD-ROM technology and OPAC to be fully integrated into the campus local area network during Fall ' 89 semester. The Library is a member of the South Dakota Library Network (SDLN), a state-wide Unisys PALS multi-type integrated online library system. Responsibilities include administration and coordination of public services in accordance with the goals of the library. Public Services includes: Reference, Bibliographic Instruction, Automated Information Access (database searching, CDROM, online catalog), Interlibrary Resource Sharing, Circulation/ Reserves, and Media Services. The position reports to the Library Director and supervises 1 FTE Library Associate and student support staff. Qualifications include an ALA-accredited MLS; relevant experience in public services; excellent written and ora communication skills; interpersonal skills necessary to work collegially and cooperatively with other library staff, faculty and campus community; experience with library automation; and a commitment to the service role of the library in an academic setting. Minimum salary $\$ 24,000$ plus benefits package. Established in 1881, DSU is located in eastern South Dakota in a region of lakes approximately

\section{Dew Mexico State University}

New Mexico State University invites applications and nominations of hiqhly qualified candidates for the position of Dean of the Library. NMSU enrolls over 14,000 students in 75 major undergraduate areas, 45 master's degrees, and 19 doctoral degree programs.

The Dean of the Library reports to the Executive Vice President and sits on the Academic Dean's Council. Responsibilities include general administration of the library, planning and budgeting, policy development, and implementation of library programs and services. The Library's collections include over 800,000 volumes and approximately 7,000 current serial subscriptions. It is a member of AMIGOS Bibliographic Council Inc. and is highly automated. A new $\$ 11.1$ million library building project will be in the construction phase. Library programs are staffed by 69 employees including 26 faculty and professionals. The annual operating budget is approximately $\$ 3.1$ million.

The candidate should have broad academic and/or research library experience; possess an understanding of a research library's role in support of graduate and undergraduate instruction, scholarship, research; be familiar with the traditional aspects of librarianship, innovative information technologies, and automated library systems; be committed to the principles of service and access to information in an academic environment; have a strong commitment to professional and staff development; have a record of participation in professional activities; have experience in library fund-raising; and possess communication, interpersonal, and management skills and leadership ability. A master's degree from a program accredited by the American Library Association is required; an earned doctorate is expected. NMSU offers a salary of $\$ 65,000$ or more based on qualifications and experience and a comprehensive benefits package.

Applications must be postmarked no later than February 15,1990. The position becomes available July 1, 1990. Applicants must submit a letter of application, resume, and the names, titles, addresses, and telephone numbers of at least three references to:

\section{Dean Thomas M. Gale Library Search Committee




\title{
The University Libraries of the University of North Texas
}

The University Libraries of the University of North Texas invite applications for the following three positions:

\section{Catalog Librarian, Serials.}

Under the direction of the Head of Bibliographic Control, the holder of this position is the Libraries' principal cataloger for serials. Duties include the supervision of one of the four units of the department; unit personnel currently supervised include one librarian, two paraprofessionals, and several student assistants. As unit head, will organize and manage workflow, act as department liaison with other units involved with serials, and provide guidance on serials to other library staff. In addition to primary duties, there is the expectation for contributions to professional service and scholarship as befits an academic appointment. Position requires five or more years experience in cataloging; demonstrated competency in LC classification and subject headings; AACR2, and MARC bibliographic formats; OCLC or similar utility; working knowledge of two or more languages; MLS from ALA-accredited program; cataloging experience in a local automated system. Preferred qualifications include 2-3 years of successful supervisory experience in a university setting, experience in serials cataloging, additional advanced degree. Appointment at the rank of Librarian II-IV, depending on qualifications, minimum salary levels for these ranks, $\$ 26,000-\$ 33,000$.

Apply to Sarah Hogan, Chair, Serials Cataloger Search Committee, address below.

\section{Fine Arts Librarian, General Reference.}

Under the general supervision of the Head of Reference, provides reference service primarily in the field of the fine arts with additional responsibilities in collection development, bibliographic instruction, database searching in assigned area, and assistance at the General Reference desk. Qualifications include MLS from an AL-accredited program, undergraduate major in the fine arts, and knowledge of database searching. Preferred qualifications include three to five years experience in fine arts reference, additional graduate degree in an appropriate area, and familiarization with computer applications in libraries. Appointment at the rank of Librarian I or II, with minimum salary levels for these ranks, $\$ 22,000-\$ 26,000$. Apply to: Martha Tarlton, Chair, Fine Arts Search Committee, address below.

\section{Science Librarian.}

Provide reference services, with an emphasis in the hard sciences, perform database searching, participate in collection development and bibliographic instruction. Operates under the general supervision of the Head of the ISB Libraries, a branch facility serving the sciences, technologies, and information science. Qualifications include a MLS from an ALA-approved program, at least three years reference experience, preferably in the sciences, and an undergraduate major in science or mathematics. Preferred qualifications include an additional graduate degree in an appropriate field, experience in online database searching, and familiarity with computer applications in libraries. Appointment at the rank of Librarian II-IV, depending on qualifications, minimum salary levels for these ranks, $\$ 26,000-33,000$. Apply to William B. Floyd, Science Search Committee, address below.

The University of North Texas is a comprehensive university with a student population of over 26,000 and is located in Denton, a community of 65,000 in the Dallas/Fort Worth metro-area. The University Libraries have collections of over 1.4 million, a full-time staff of 114 , and operating budget of over $\$ 4.5$ million.

All positions are currently available, are 12-month appointments with renewable contracts, and include standard benefits. To ensure full consideration, applications should be received by January 31, but applications will be accepted until the positions are filled. Submit a letter of application, complete resume, names, addresses and telephone numbers for three references to:

\author{
(Name and search committee listed above) \\ c/o Administrative Offices, University Libraries \\ University of North Texas \\ P.O. Box 5188 \\ Denton, TX 76203
}

UNT is an affirmative action, equal opportunity employer. 
45 minutes from Sioux Falls. The university enrolls approximately 1,200 students and is an exciting undergraduate institution. The newly-remodeled Mundt Library provides an attractive and wellused environment for study and teaching. The library and campus administration encourage participatory management, open communication, and staff development at all levels of the organization. Applications received before February 28, 1990, will receive first consideration. Some preliminary interviews be held at ALA Midwinter. Please send letter of application, resume, transcripts, and names of three references to: Ethelle S. Bean, Director of the Library, Karl E. Mundt Library, Dakota State University, Madison, SD 57042 . AA/EOE.

REFERENCE/BIBLIOGRAPHIC INSTRUCTION LIBRARIAN. St. Olaf College seeks a librarian with 3-5 years experience to work with other reference librarians in its strong program of course-integrated bibliographic instruction, to share reference duties (including evenings and weekends) and to supervise the circulation/reserve department. Proven skill in bibliographic instruction essential, preferably in religion and education; knowledge of online circulation systems useful. ALA-MLS required; additional graduate study and/or evidence of professional activity desirable. Faculty status (tenure-track) and responsibilities; TIAA-CREF. 10-month schedule. Salary commensurate with experience, minimum $\$ 26,000$. St. Olaf is a college of the Evangelical Luthran Church in America and an equal opportunity/ affirmative action employer. Send resume and names of three references to: Librarian Forrest Brown, Rolvaag Memorial Library, St. Olaf College, Northfield, MN 55057, by February 15.

REFERENCE/CIRCULATION LIBRARIAN. Search extended. ALA-accredited MLS degree required. Supervisory ability and communication skills necessary. Interest in computerized systems desired. Duties include direct reference, bibliographic instruction, reference collection development, circulation supervision, circulation policy decisions, work with automated circulation system, maintenance of collection, some night and weekend work. Salary minimum $\$ 20,000$, negotiable and competitive. Faculty rank, tenure-track position. Send application, resume and three references to: Gwen Creswell, James Earl Carter Library Georgia Southwestern College, Americus, GA 31709. Applications considered until position filled. Affirmative Action, Equal Opportunity Employer.

REFERENCE LIBRARIAN, Cornell University School of Hotel Administration Library. Responsible, under the direction of the Head Librarian, for the operation of reference service and collections in the SHA Library, including reference desk service, database searching, bibliographic instruction, and liaison with faculty in academic areas. Requirements: MLS, $2-5$ years in library public services; database search skills; knowledge of business reference sources. Public orientation, excellent interpersonal skills, good written and verbal communication skills, and demonstrated evidence of initiative and creativity. Salary (with 2 yrs. or more experience) $\$ 22,000$ up. Send cover letter, resume and names of 3 references, by January 30, 1990, to Ann Dyckman, Personnel Director, 201 Olin Library, Cornell University, Ithaca, NY 148535301. Cornell University is an affirmative action, equal opportunity employer.

REFERENCE LIBRARIAN, Doheny Memorial Library. Provides reference desk service, online search service (in both the humanities and the social sciences), and a variety of bibliographic instruction programs. Prepares and compiles research guides for the Reference collection, and, in consultation with the Head provides collection development support in subject areas relating to the humanities or the social sciences, specifically in English/ American Literature, Comparative Literature, Linguistics or Performing Arts (excluding Cinema). MLS/ALA, with an undergraduate degree in the humanities or the social sciences; reading knowledge of German or a Romance Language; demonstrable expertise at database searching; classroom or other formal teaching experience; bibliographic instruction content development and evaluation experience, especially at the graduate level. Preferred: A second degree beyond the bachelor's degree; prior experience in an academic library; strong online search experience in humanities and social sciences databases available through DIALOG, BRS, or WILSON; experience with a variety of software interfaces for end-user search systems; awareness of available library-oriented, knowledge-based, or expert systems.
Salary: Librarian II, $\$ 32,000$; Librarian III, $\$ 37,900$, minimum salary, plus benefits. Position open: March 1, 1990, and will remain open until filled. Apply to: Carolyn J. Henderson, Associate University Librarian for Administrative Services, Doheny Memorial Library, University of Southern California, University Park, Los Angeles, CA 90089-0182. Applicants should submit a letter of application; resume; and names, addresses and telephone numbers of three references. Refer to Reference Librarian, Position \#134-CRL. AA EOE.

REFERENCE SERVICES COORDINATOR, Whitworth College. Provide coordination and leadership for reference services, including online and CD-ROM searching. Participate in ambitious bibliographic instruction program. Qualifications: MLS or equivalent. Additional graduate degree preferred (required for faculty track appointment). Subject background in education, natural sciences, or social sciences desirable. Effective interpersonal and teaching skills. Compensation: Determined by faculty or classified staff salary schedule, as applicable. Minimum $\$ 22,000$ for 11 -month appointment. Send resume, placement file or names of three references by January 31, 1990 to: Reference Librarian Search Committee, Personnel Office, Whitworth College, Spokane, WA 99251. Whitworth is a residential, Christian, liberal arts college affiliated with the Presbyterian Church (U.S.A.). EOE/IX/504

REFERENCE/TECHNICAL REPORTS LIBRARIAN. The University of Maryland College Park Libraries invites nominations and applications for the position of Reference/Technical Reports Librarian, Associate Librarian II. Engineering \& Physical Sciences Library, Reference Unit. Associate Staff, full-time, 12-month appointment. Salary: $\$ 24,384-\$ 34,342$. Salary commensurate with experience. Responsibilities: Provides specialized and general reference service, database searching and bibliographic instruction in EPSL subject areas, including engineering, physics, mathematics, computer science, and earth science; assumes managerial responsibilities for the daily operation of Technical Reports Center; facilitates and promotes the effective use of a very large (1.5 million +$)$ and varied scientific and technical documents collection; assists users of the EPSL Patents collection; selects materials in assigned areas. Qualifications: Required: MLS from an ALA-accredited program. Education, background or experience with research materials in one or more science disciplines, particularly in engineering or the physical sciences, is highly desirable. A degree in a science discipline is desirable. Experience: Required: A minimum of one year professional library experience; knowledge of the organization and maintenance of technical reports or government documents collections; demonstrated effective oral and written communications abilities; proven managerial ability, analytical skills and organizational ability; evidence of thorough familiarity with the literature of science and technology; established commitment to public services. Highly desirable: successful previous supervisory experience; skill in use of automated reference sources and experience in use of scientific databases; experience in working with an online public access catalog; Instructional skills/experience; experience in collection development. Benefits: 22 working days annual leave; 14 paid holidays; 15 days sick leave; University contributions to hospitalization, major medical insurance, and retirement (State pension system or TIAA/CREF); tuition remission for self and dependents. Position available immediately. Applications: For full consideration, submit resume and names/addresses of 3 references by February 28, 1990, to: Marjorie Simon, Library Personnel Office, McKeldin Library, University of Maryland, College Park, MD 20742-7011. The University of Maryland is an affirmative action, equal opportunity employer.

RESEARCH SUPPORT SERVICES LIBRARIAN. The Arizona State University West Campus Library seeks applications from opportunity-seeking, dynamic, energetic, and creative librarians to join a department of 4.5 librarians and 6 paraprofessionals. Responsibilities: reference and research support, including an innovative partnership with paraprofessional information providers, individual consultation with students and faculty on research projects, and delivery of online services; bibliographic instruction in assigned subject areas; and collection development in specific disciplines with emphasis on a strong liaison role with the faculty. Participates in program development and improvements. Minimum qualifications: an ALA-accredited MLS; minimum of 1 year post MLS; experience in an academic setting providing reference, online searches, and bibliographic instruction; experience in selection of materials and development of library collections; excellent interper- 


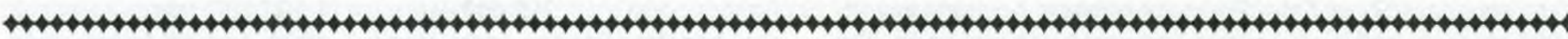 \\ DIRECTOR OF THE BIO-MEDICAL LIBRARY
} Ln

\author{
University of Minnesota-Twin Cities
}

The director of the Bio-Medical Library is responsible for the administration of the University of Minnesota Bio-Medical Library which interacts closely with and supports the teaching programs of the Schools of Medicine, Dentistry, Nursing, Public Health, the College of Pharmacy, certain biological sciences, and the University Hospital and Clinic. The Bio-Medical Library is located in the health sciences complex on the University's Minneapolis campus and includes a learning resources center, the Wangensteen Historical Library of Biology and Medicine, and an automated technical processing unit. The Library has a total operating budget of more than $\$ 2,000,000$ and a staff of $47 \mathrm{FTE}$. It has a collection of over 350,000 volumes and 4,000 active journal subscriptions and is one of the strongest collections among health sciences libraries in the country. The Bio-Medical Library has a very active service program and is well positioned for potential IAIMS development. The University Libraries utilize the NOTIS software system for its online catalog (LUMINA).

The director of the Bio-Medical Library reports to the University Librarian and is a member of the administrative staff of the University Libraries. The director is an ex-officio member of the Bio-Medical Library Advisory Committee, which meets regularly to advise regarding the programmatic directions of the Bio-Medical Library.

Responsibilities: Develops policies and establishes program priorities for the Bio-Medical Library and seeks support for innovative programs, such as IAIMS; is responsible for the management of the BioMedical Library, including budget and operations; works closely with health sciences departments in the development of programs and services that support the educational, research, and information needs of faculty, students, and clinicians; participates in the administration of the University Libraries as a member of the Central Administrative Group and serves on Libraries committees; represents the University Libraries in health sciences matters at local, state, regional, and national health sciences library and related professional activities.

Qualifications: A graduate degree from a program accredited by the American Library Association is required, an advanced degree in a health related field is desirable; a minimum of five years of professional library experience with progressively increasing administrative responsibility is required, experience in an academic health science setting is desirable; knowledge and understanding of current issues, trends and problems in academic health sciences librarianship including electronic information systems is required; demonstrated skills and accomplishments in planning and implementing information services is required; demonstrated ability to work effectively with faculty, students, academic administrators, library colleagues, and representatives of the surrounding health sciences community is required; record of substantial professional activities and accomplishments including grant applications and/or publications is required; evidence of the vision and administrative and planning skills to continue the development of an innovative, technologically advanced health sciences library is required.

The University of Minnesota's Twin Cities campus is located on the Mississippi River just minutes away from downtown Minneapolis and downtown St. Paul. The University is one of the nation's leading research institutions with a student body numbering more than 45,000 . The Libraries are among the top ten state universities in collection size and are the first major research libraries to have completed retrospective conversion of bibliographic records. The successful candidate for this position will join a team of wellqualified managers who are committed to making the Libraries the very best in the United States. He or she will have an extraordinary opportunity to exercise leadership within a dynamic collegial environment.

This is an academic-administrative appointment, which offers a generous range of benefits. The salary is highly competitive and negotiable depending on experience and qualifications.

Applicants should send a letter of application relative to the above description; a current resume; and names, addresses, and telephone numbers of at least five references to:

\author{
Barbara Doyle, Personnel Officer \\ University of Minnesota Libraries \\ 453 Wilson Library \\ 309 19th Avenue South \\ Minneapolis, MN 55455
}

Applications must be received by March 1, 1990. Please cite UL 189 on application.

The University of Minnesota is an equal opportunity educator and employer and specifically invites and encourages applications from women and minorities. 
sonal skills; demonstrated ability to market and promote library services in a new environment; evidence of creativity and initiative in professional practices. Preferred qualifications: subject expertise, demonstrated by substantial reference or collection development experience and/or an undergraduate degree in business or the social sciences. For appointment as Associate Librarian, salary \$27,000 minimum: Must exceed minimum criteria for appointment and have five or more years of experience; demonstrate a substantial record of service and contributions to librarianship and/or an applicable academic discipline. For appointment as Assistant Librarian, salary $\$ 22,000$ minimum: Must meet the mini- mum criteria for appointment. About ASU West: The West Campus is a newly founded and rapidly growing upper-level branch campus with exceptional faculty and students. The Library offers an elegant new 97,000 square foot building, a program emphasis on quality services tailored to institutional and client needs, collection building coordinated with curriculum building, a $\$ 1.5$ million acquisitions budget, intensive use of electronic information technology, and partnership with faculty in the academic mission. An online catalog provides access to both West Campus resources and the collections of ASU in Tempe. ASU West Campus currently enrolis 4,000 students and offers a diverse curriculum. To apply: A letter of

\section{TWO POSITIONS}

\section{University of Northern Colorado Libraries}

Director of Access Services and Budgets (Assistant or Associate Professor). The Director of Access Services and Budgets is a member of the University Libraries administration and reports directly to the Director of University Libraries.

Responsibilities: Management of the Access Services Division comprised of the acquisition/serials, circulation/periodicals, cataloging, and interlibrary loan departments; budget preparation and expenditure authorization for an operating budget of $\$ 2.1$ million and a materials budget of $\$ 1.1$ million; monitors automation needs, including OCLC and CARL, and supervises implementation as necessary.

Required Qualifications:ALA-accredited MLS degree; progressive experience in technical services with a minimum of 5 years administrative/supervisory and budgeting experience; experience with computerized library systems.

Salary and Rank: Beginning salary range is $\$ 38,000-\$ 44,000$ with rank of assistant or associate professor dependent on qualifications and experience and a demonstrated commitment to scholarly activity. Appointment will be on a term contract. Benefits may include health, life, and dental insurances and the Colorado Public Employees Retirement Program in accordance with University policy.

Acquisitions/Serials Librarian (Assistant Professor). The Acquisitions/Serials Librarian is a faculty position and reports directly to the Director of Access Services and Budgets.

Responsibilities: Supervision of 6.5 FTE classified staff and numerous student assistants; management of the acquisitions/serials department which is responsible for monographic and serials acquisitions, including ordering, check-in and receiving, serials cataloging, completion of serials retrospective conversion, gift processing, invoice processing and payment, and the library mail room. These operations are automated through the CARL system.

Required Qualifications: ALA-accredited MLS degree; minimum of two years experience in acquisitions and/or serials in a college, university, or research library; experience with computerized library systems.

Salary and Rank: Minimum salary of $\$ 25,800$ with rank of assistant professor. Appointment will be on a tenure-track contract. Benefits may include health, life, and dental insurances and the Colorado Public Employees Retirement Program in accordance with University policy.

The University: The University of Northern Colorado, a senior public institution, is located in Greeley, Colorado. The academic enrollment is approximately 9,000 students with about 450 faculty. Greeley is located 50 miles north of Denver, 50 miles east of Rocky Mountain National Park, and has a population of 62,000. Application Procedure: All application materials must be received no later than March 1, 1990. Send letter of application, vita, and three current letters of reference to the Director of Access Services and Budgets Search Committee or Acquisitions/Serials Librarian Search Committee, as appropriate, at the following address:

\section{c/o Administration Office \\ James A. Michener Library \\ University of Northern Colorado \\ Greeley, CO 80639 \\ Telephone: (303) 351-2601}

There is a University policy which precludes selection individual to tenure-track positions whose terminal or highest degree is from the University of Northern Colorado, except in unusual circumstances, as determined by the President of the University.

The University is an Affirmative Action/Equal Opportunity Employer. Qualified women, minorities, veterans, and disabled persons are encouraged to apply. 
application addressing specific qualifications as they relate to the responsibilities described, a current resume, and the names, addresses, and telephone numbers of 4 references must be postmarked by March 15, 1990 and sent to Helen L. Gater, Director Fletcher Library, Arizona State University West Campus, P.O. Box 37100, Phoenix, AZ 85069-7100. ASU West Campus is an Equal Opportunity Affirmative Action Employer.

SERIALS LIBRARIAN, Pembroke State University, a campus of the University of North Carolina. To begin February 1990. Manages the purchase, receipt, storage, display, and preservation functions of periodicals; supervises two employees. Knowledge of library computer applications and serials management required; pertinent experience desirable. ALA-accredited MLS required; salary range $\$ 20,000-\$ 25,000$. Send letter of application, resume, and three letters of recommendation to: Elinor Bridges, Director of Library Services, Mary Livermore Library, Pembroke State University, Pembroke, NC 28372. Preference given to those who apply by January 18, 1990. AA/EOE.

SYSTEMS COORDINATOR, with faculty rank. Search reopened. Coordinates ongoing development of library's automated system (NOTIS); supervises database maintenance activities (catalog ing, authority control); coordinates use of IBM microcompute classroom including software and applications instruction. Required: MLS from an ALA-accredited program or MS in information science. Strong communication skills and the ability to work effectively with students, faculty, and colleagues. Preferred: dem onstrated knowledge of latest developments in micro-based applications and library automated systems in an academic environment. Salary: minimum $\$ 22,000$, commensurate with experience. Send letter of application, resume, transcripts, and 3 letters of recommendation to: David W. Jordan, Vice-President for Academic Affairs, Austin College, Sherman, TX 75091-1177. Review of candidates will begin February 1, 1990. EOE.

TECHNICAL SERVICES LIBRARIAN, Austin Presbyterian Theological Seminary (Search reopened). To assume primary responsibility for cataloging. Duties also include overseeing acquisitions processing, supervising student assistants, and maintaining public catalog and shelf list. The Technical Services Librarian will also play a major role in choosing and implementing an automated system for library procedures. Qualifications: ALA accredited MLS, two years cataloging experience using OCLC or similar bibliographic utility. Preference will be given to applicants with knowledge of automated library systems and a background in religious studies. Salary: $\$ 22,000-\$ 26,000$. Excellent benefits AAVEEO. Send application with three references or dossier to: Valerie R. Hotchkiss, Stitt Library, Austin Presbyterian Theological Seminary, 106 W. 27th St. , Austin, TX 78705. Application deadline: January 10, 1990

TECHNICAL SERVICES LIBRARIAN, St. Olaf College. Plan and guide the work of technical services, including cataloging, technical aspects of acquisitions, and bibliographic aspects of automation for a liberal arts library adding over 12,000 volumes/year and receiving more than 1650 periodical titles. Will work with 2 catalog librarians, 1 part-time serials records librarian, staff and students in acquiring and cataloging all library materials for an integrated automated system (PALS). Required qualifications: ALA-MLS minimum of 5 years cataloging experience; strong supervisory and interpersonal skills demonstrated through experience, preferably in an academic library; thorough knowledge of AACR2, MARC formats, LC classification and subject headings; experience with automated systems (preferably OCLC); reading knowledge of foreign languages (preferably Germanic and Romance). Additional graduate degree and/or evidence of professional activity desirable. A full-time, 10-month, faculty tenure-track position with initial appointment as assistant or associate professor. Salary commensurate with experience, minimum $\$ 27,000$. St. Olaf is a college of the Evangelical Lutheran Church in America and an equal opportunity affirmative action employer. Send resume and names of three references to Librarian Forrest Brown, Rolvaag Memorial Library, St. Olaf College, Northfield, MN 55057, by February 15

UNIVERSITY LIBRARIAN, Rice University invites applications and nominations for the position of University Librarian. Fondren Library (a member of ARL) contains over 1.4 million volumes, more than 1.5 million special materials [government publications, microforms, maps, audio-visuals, and computer software], and almost 13,000 serials. The current operating budget is over $\$ 5$ million. Rice University is comprised of 7 schools, has an enrollment of about 4,000 , and 470 faculty. The library presently has 36 professional positions and 76 support staff. Fondren also includes the Regional Information and Communications Exchange, a fee-based information brokerage for the community. Preference will be given to candidates with an ALA-accredited MLS and second advanced degree or equivalent academic training, who have knowledge and proven experience with major research libraries and their operations, have at least five years of senior managerial experience, and are aware of current library issues and technologies. Candidates should also be aware of and sympathetic to the library needs of the entire university community, able to maintain friendly and cooperative relationships with all library users, and able to communicate effectively on behalf of the library with its various administrative and community supporters. The position is a 12-month administrative appointment with a five year renewable term appointment; tenure in a department is possible if properly qualified in one of the academic departments of the University. The University Librarian reports directly to the Vice President for Graduate Studies, Research, and Information Systems. Salary: $\$ 80,000$ range. Benefits: TIAACREF annuity program; $43(B)$ program; flexible benefits plan including life, health, and dental insurance; undergraduate tuition waiver for family members; no state or local income taxes. Rice University is an EO/AA employer. Closing date: applications should be received by February 1 1990, but the position will remain open until filled. Applications, accompanied by a complete curriculum vitae and the names and addresses of five references, should be sent to: Katherine F. Drew, Chair, University Librarian Search Committee, c/o Office of the Vice President for Graduate Studies, Research, and Information Systems, Lovett Hall, Rice University, Houston, TX 77251-1892.

\section{LATE JOB LISTINGS}

ASSOCIATE LIBRARIAN FOR TECHNICAL SERVICES, University of Windsor, Leddy Library. The University of Windsor is seeking an individual with strong management skills and administrative experience to head the Technical Services Division of the Leddy Library. Reporting to the University Librarian, the Associate Librarian administers the cataloguing, acquisitions, and bindery functions of the Library. The Library has recently implemented two modules of the NOTIS integrated system, cataloguing and circulation. The Technical Services Librarian will work closely with the Automation Librarian to plan and implement the serials, acquisition, and authorities modules of NOTIS as well as to continually enhance and develop automated functions and work flow in technical services. The Associate Librarian serves on the University Librarian's management team and participates in the formulation, planning, and implementation of goals, policies, and priorities of the Library and in the allocation of resources of the Library. An MLS from an accredited library school, substantial administrative experience, competence in 
technical services, and effective written and oral communication skills are required. Experience in an integrated automated environment, demonstrated leadership abilities, the ability to manage change, and commitment to a style of management which emphasizes consultation and effective interrelationship of technical and public services are highly desired. Salary will be commensurate with experience and qualifications. Current minimum salary is 39,000 Canadian dollars. The University of Windsor is Canada's southernmost university and offers excellent academic benefits, including eligibility for sabbatical and study leaves. The Leddy Library serves 9,687 full-time and 4,711 part-time undergraduate and graduate students with an annual materials budget of $\$ 1.5$ million. The city of Windsor and the surrounding area offer a rich variety of cultural and recreational pursuits. In accordance with Canadian Immigration requirements, priority will be given to Canadian citizens and permanent residents of Canada. The University of Windsor is an equal opportunity employer. Women are especially encouraged to apply. Applicants should send their curriculum vitae and the names of three referees to: Madge MacGown, University Librarian, University of Windsor, Windsor, Ontario, Canada N9B 3P4.

AUTOMATION LIBRARIAN. Management of VTLS system, microcomputer applications, CD-ROM facilities. Installs new releases, runs programs, monitors activities, trains staff, liaison for library with Computer Center. Requires ALAaccredited MLS, knowledge of COBOL, 2 years experience minimum. Prefer computer (mini and PC) experience, coursework, knowledge of OCLC, VTLS, DIALOG. Salary commensurate with experience (range $\$ 23,000-\$ 30,000$ ). State contributed retirement, insurance package. No state income tax. Resume, letter of application, three references to: Personnel Department, University of HoustonClear Lake, 2700 Bay Area Blvd., Houston, TX 77058. Available February 1. EEO, affirmative action employer.

BIBLIOGRAPHIC INSTRUCTION LIBRARIAN, St. Mary's College of Maryland. St. Mary's is a publicly supported liberal arts college (1495 FTE) with no religious affiliation. It is located in beautiful tidewater country seventy miles southeast of Washington, D.C. The college library will occupy an expanded a totally renovated building in the summer of 1990 . Over the course of 1990 it will also be bringing up an integrated online system, in part to assist with the management of greatly augmented operating revenues. Responsibilities of the position: To coordinate the development and presentation of course-related bibliographic instruction sessions; to provide assistance in mediated and end-user database searching; to assist in preparing bibliographic and other user aids; and to share in providing traditional reference desk assistance. Some evening and weekend service is required. Qualifications: A strong and energetic commitment to bibliographic instruction; experience in a established bibliographic instruction program; ability to create good working relationship with faculty and students; MLS or equivalent degree from ALA-accredited program. Salary: $\$ 25,000-\$ 28 ; 000$ depending upon experience. TIAA/CREF or Maryland State Pension System, as well a State of Maryland executive benefit package, are included. Review of applications will begin on March 1, 1990. The position will available on June 30, 1990. Send letter of application, resume, and the names of three professional references to: John G. Williamson, Director of the Library, St. Mary's College of Maryland Library, St. Mary's City, MD 20686 (301) 862-0256. Women and minority candidates arc especially encouraged to apply and to identify themselves as such. AA/EOE.

DIRECTOR OF LIBRARIES, University of Wisconsin-Eau Claire. The University of Wisconsin-Eau Claire invites applications for the position of Director of Libraries. This annual appointment, which includes faculty rank, will begin on July 1,1990 , or as soon thereafter as possible. Salary will be commensurate with 
qualifications (minimum $\$ 41,900$ ). McIntyre Library has a collection of more than 500,000 volumes, 200,000 government documents, 990,000 microforms, and 2,300 current periodical subscriptions. It is a Selective Federal Depository and a comprehensive Wisconsin Documents Depository. Special facilities include an Instructional Media Center and a regional historical research center. Automated activities include participation in OCLC online cataloging, LS/2000 public access catalog and circulation system, SC350, ACQ350, remote database access, and a variety of enduser reference services. The Director of Libraries reports to the Assistant Chancellor for Information and Technology Management and is responsible for the management of library services in a collegial environment. The Director must be familiar with current developments in librarianship and appropriate uses of technologies for information services. Currently the Director supervises 12 professional librarians with faculty rank and status and 20 (FTE) classified staff members. A major opportunity for the new Director will be the implementation of a $\$ 9$ million building project, including plans for the formation of a technology center. Qualifications include strong academic credentials, including an MLS degree from an ALAaccredited library school and a second advanced degree in an academic discipline (doctorate preferred); a clear and coherent view of librarianship and service to an academic community; a commitment to the concept of active participation of the library in the curriculum; knowledge of the place and use of information technology in the university setting; a record of successful management, long-range planning, and implementation; professional experience in an academic library, including supervision of other librarians; evidence of scholarly and professional achievement; analytical and communication skills; prior budgetary responsibility. Responsibilities include supervision of all technical, public service, and administrative functions of the Library, including: programmatic planning, budget, personnel selection and evaluation, and maintaining appropriate programmatic liaison with other academic and administrative units of the University, as well as with libraries and institutions outside the University. The University of Wisconsin-Eau Claire has an enrollment of 10,000 students and a faculty of 660 . It offers programs at the baccalaureate and masters levels in five schools: Arts and Sciences, Business, Education, Nursing, and Graduate Studies. Often called "Wisconsin's most beautiful campus," the University is located in Eau Claire, a city of 55,000, which serves as a trade, medical, and recreational center for Western Wisconsin. It is 90 miles east of Minneapolis-St. Paul. Applications must include a letter of intent, a resume of professional experience, and five current reference letters and official transcripts sent directly from the sources. All application materials should be sent to: Harry Harder, Associate Vice Chancellor, Schofield Hall, University of Wisconsin-Eau Claire, Eau Claire, WI 54701. Review of applications will begin on February 12, 1990, and will continue until the position is filled. Applications received after March 1,1990 , cannot be assured of consideration. The University of Wisconsin-Eau Claire is an affirmative action, equal opportunity employer and welcomes applications from qualified handicapped, minority, and women candidates.

DIRECTOR OF LIBRARIES, Lafayette College. Administers all aspects of the main library and one departmental library, with a staff of 10 librarians and 14 support personnel. The libraries hold 400,000 volumes and receive 1,800 periodicals, with all modules of the Innovative Interfaces system in place. 12-month appointment beginning July 1, 1990, carries faculty status but not faculty rank or tenure. Candidates must have substantial experience in library administration, an MLS from an ALA-accredited program, and a second master's degree in subject field. A Ph.D. is highly desirable. Lafayette College is an independent, coeducational, residential college of approximately 2,000 students and 161 faculty members, unique for its rare combination of liberal arts and engineering in an exclusively undergraduate institution. Minimum salary $\$ 50,000$. Please send nominations and applications to: Director of Libraries Search Committee, Lafayette 
College, 219 Markle Hall, Easton, PA 18042. Applications should include a letter of interest, a resume, and the addresses and telephone numbers of three references. Lafayette College is an equal opportunity employer.

HEAD, ACQUISITIONS SECTION, Michel Orradre Library, Santa Clara University. (Readvertised Position) Manages operations of Acquisitions Section; supervises 5 FTE non-exempt staff; oversees firm orders, serial subscriptions, domestic approval plans, out-of-print orders, and gift processing; serves as primary liaison with University's Business Office concerning acquisitions budget of approximately 1 mil. dollars; coordinates acquisitions procedures with bibliographers. Required: MLS or equivalent degree from ALA-accredited program; at least 2-3 years of relevant professional experience; prior experience as supervisor or manager; strong interpersonal and communication skills; experience with automated systems; and familiarity with the book trade. Desirable: experience with OCLC; collection development experience; and knowledge of at least one modern foreign language. Initial appointment at Senior Assistant or Associate Librarian rank, depending upon qualifications. $1989 / 90$ salary range $\$ 28,222$ - $\$ 46,560$. Candidates who do not meet all requirements will be considered for appointment at lower rank. Apply by March 1, 1990 to: Elizabeth M. Salzer, University Librarian, Michel Orradre Library, Santa Clara University, Santa Clara, CA 95053. Santa Clara is an AA EO employer.

LIBRARY GRADUATE ASSISTANTS for 1990 academic year. Mankato State University is seeking individuals who possess either an MLS or MA in Library Science and who wish to work on a subject master degree while gaining valuable professional experience in an academic library. MSU offers master degrees in over 60 academic disciplines. Graduate assistantships are internships in the discipline-in this case, two disciplines-library science and the subject discipline of your choice. Graduate assistants supervise student workers and perform other professional services in the public and technical services of the Library. Public service positions include reference, government publications, online database searching, interlibrary loan, educational resource center, media production, circulation, maps, periodicals, and bibliographic instruction. Positions in the technical services include acquisitions, cataloging, and library research. Successful candidates must show evidence of demonstrable working experience in one of the areas listed. A full assistantship averages 20 hours of work and pays $\$ 163$ per week for 34 weeks of the academic year. Eleven-month assistantships are also available. Additionally, graduate assistants qualify for in-state tuition and for at least onehalf tuition remission of 6 to 12 graduate credits per quarter during the academic year. Mankato State University Library, a dynamic information center for over 16,000 students and area users, has a staff of 25 librarians, 24 classified staff, 20 graduate assistants, and over 200 student workers. Memorial Library is the home of the PALS automated system, a nationally known integrated library system featuring an online catalog, a circulation system, an interlibrary loan module, a serials control system, and an acquisition system. Authority control and inventory control are under development. A letter of application outlining your experiences in an academic library, your resume, and the names and telephone numbers of three current references should be sent to: Thomas M. Peischl, Dean of the Library, Mankato State University, MSU Box 19, P.O. Box 8400, Mankato, MN 560028400; (507) 389-5953. Applications from minorities are encouraged; Mankato State University is an equal opportunity University and employer.

SERIALS CATALOGING UNIT HEAD, Otto G. Richter Library, University of Miami. Reports to the Head of the Catalog Department. Catalogs new serials according to AACR2 and OCLC serials format. Directs and supervises the workflow of the periodicals processing unit (6 paraprofessional FTE); studies way to improve 
or modify local practices of processing periodicals. Prepares for future automation needs and the classifying of periodicals. Prepares for future automation needs and the classifying of periodicals. Serves on library and university committees as needed. Qualifications: ALA-accredited MLS or its foreign equivalent and serials cataloging experience. Preferred: managerial experience in a serials cataloging unit of an academic library. Appointment: Faculty rank of Assistant Professor, tenure earning, twelve-month. Librarians are expected to meet the University's criteria for tenure which requires research and publication. Benefits: Paid pension plan; partially paid insurance plans; 22 days vacation; moving allowance; tuition remission; beaches, sun. Salary: starting salary range $\$ 23,000-\$ 30,000$ depending on experience and qualifications. To ensure consideration, apply before February 15 , 1990. Send application letter, resume, and the names of three references to: Ronald P. Naylor, Assistant Director for Administrative Services, Otto Richter Library, University of Miami, P.O. Box 248214, Coral Gables, FL 33124. An Equal Opportunity, Affirmative Action Employer.

SYSTEMS LIBRARIAN/PROJECT DIRECTOR (search reopened) to manage and coordinate the planning, implementation and evaluation of an integrated online library system. Requires: MLS; broad-based knowledge of library operations; 2 years working experience with automated system in an academic library; experience with OCLC; demonstrated understanding of current and developing library technologies; excellent analytical, organizational, and communication skills. Appointment range: $\$ 30,000-\$ 34,000$; comprehensive benefits package. Applications accepted until January 15 or until position is filled. Application, resume and names, addresses, and telephone numbers to: George M. Telatnik, Director, Canisius College Library, 2001 Main Street, Buffalo, NY 14208. An Equal Opportunity Employer.

TECHNICAL SERVICES HEAD to catalog, oversee materials budget, and supervise acquisitions and catalog departments in a four-year college. Occasional reference duty. Salary from $\$ 32,000$, depending on qualifications. Position open in summer 1990 or sooner. Minimum requirements: MLS from ALA-accredited library school, suitable experience in cataloging with OCLC and AACR2, including original cataloging; experience in library automation as online system is anticipated; willingness to learn acquisitions work; good interpersonal relations and communication skills. Faculty position, 12-month contract, 30 days vacation, excellent fringe benefits, possibility of housing assistance. Send resume, letter of application, and names of three references to: James E. Gaines Jr., Head Librarian, Virginia Military Institute, Lexington, VA 24450. Applications will be accepted until the position is filled. AA/EEO Employer. 


\section{ATre Publications}

\section{New Publication:}

Preservation Microfilming: Planning \& Production. 72p., September 1989 ISBN 0-8389-7324-8 \$12.00

Papers from the RTSD Preservation Microfilming Institute, New Haven, Connecticut, April 21-23, 1988. Chapters by Wesley Boomgaarden, Myron Chace, Margaret Byrnes, Patricia McClung, Carolyn Harris, and Gay Walker.

\section{Related Works from the Association for Library Collections \& Technical Services:}

Preservation Education Directory. Compiled by Susan G. Swartzburg, Rutgers University, for the PLMS Education Committee. 32p., June 1988 ISBN 0-8389-7225-X $\$ 4.00$

A Core Collection in Preservation. Compiled by Lisa L. Fox, SOLINET, for the PLMS Education Committee. 24p., June 1988 ISBN 0-8389-7224-1 $\$ 5.00$

Order from ALA Publications, 50 East Huron Street, Chicago, IL 60611

\section{LOOKING FOR A JOB?}

ACRL's Fast Job Listing Service brings you job notices four weeks before they appear in College \& Research Libraries News. This monthly bulletin also contains job postings that, because of narrow application deadlines, do not appear in $C \& R L$ News.

The Fast Job Listing Service is sent to subscribers by first-class mail the first week of every month. You can be a step ahead of other job applicants by seeing position descriptions very shortly after they are received in our office.

Subscriptions to the Fast Job Listing Service are for a period of six months - by that time we hope you have found the job you're looking for! The cost is $\$ 15$ for ACRL members and $\$ 20$ for non-members.

You may use the form below to enter your subscription.

YES! I want to see job notices as quickly as possible by subscribing to ACRL's Fast Job Listing Service.

I I am a member of ACRL and am enclosing $\$ 15$.

$\checkmark$ I am not a member of ACRL and am enclosing \$20.

NAME:

ADDRESS:

\section{CITY/STATE/ZIP:}

Please make checks payable to ACRL/ALA and send to the Fast Job Listing Service, ACRL/ALA, 50 E. Huron Street, Chicago, IL 60611. 


\section{There are book counters- and Book Counters...}
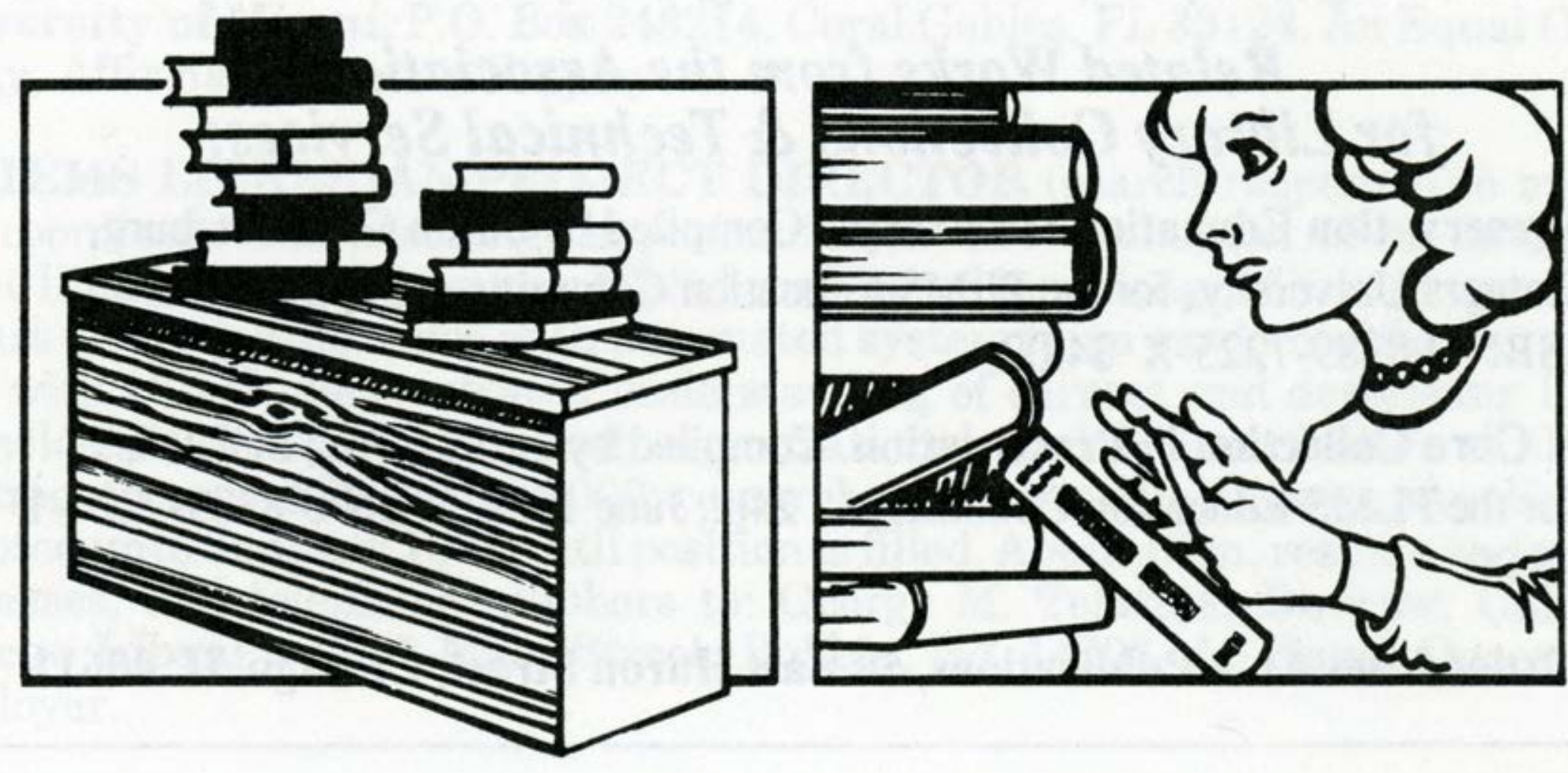

\section{But WIS Book Counters Are Fast, Accurate, and Cost-Efficient.}

Washington Inventory Service is the national leader in library inventory counting procedures. Our experienced personnel are equipped with inventory data collectors which read your books' bar codes. days in a format compatible with your present then there's WIS.

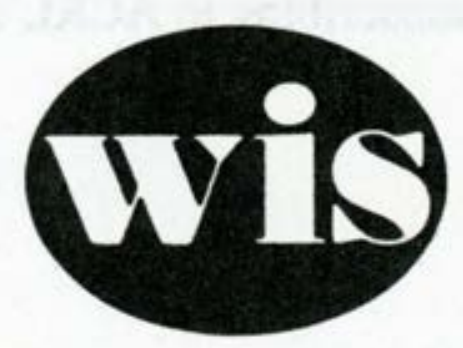

\section{WASHINGTON INVENTORY SERVICE}

A Huffy Company

General Offices:

7150 El Cajon Boulevard San Diego, CA 92115 


\section{"I've traveled over}

250,000 miles in 10 years just to 'be there' for my

\section{customers.}

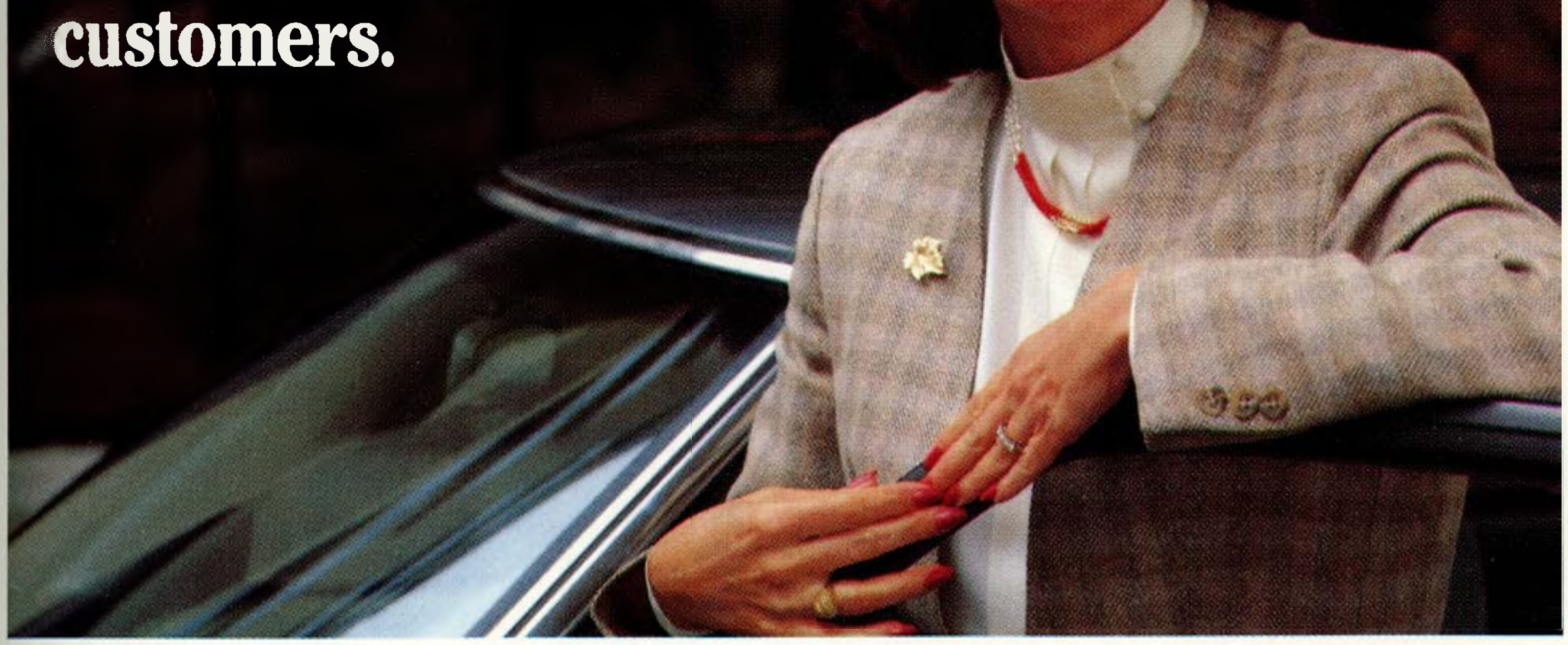

"I've worn out about 10 sets of tires traveling from New Jersey to Pennsylvania to Connecticut and back visiting academic librarians. And I guess I've been through 40 pairs of shoes in that time. But at EBSCO we feel that to offer truly professional service we must offer truly personal service.

"In fact, EBSCO has built its entire operation around the concept of being there for our customers. We've located fully staffed and equipped subscription processing centers near enough to our customers to make in-person calls a routine occurrence. And the serials support group located at each of these offices is composed of trained professionals dedicated to responding to your needs quickly and effectively.

"EBSCO realizes that its relationship with academic librarians is actually a challenging and sensitive partnership ... one that requires its representatives to display not only serials knowledge and expertise, but also conscientiousness and genuine concern for customer needs. That's why I make myself available whenever I'm needed, whether in person or by phone ... why I perform inservice training for new customers . . . why I use my experience to foresee and forestall potential problems with your subscription program . . . whatever it takes."

Audrey Greene Sales Representative

At EBSCO, we think academic librarians should be served by experienced serials professionals who will 'be there' for them. Isn't that what you expect from a professional subscription agency?

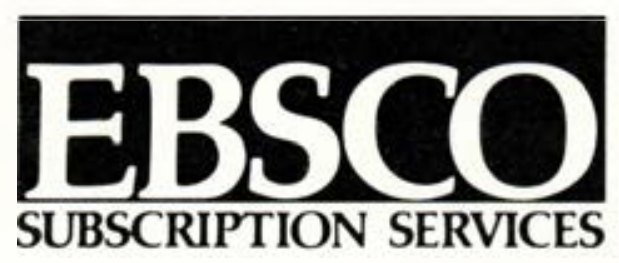

International Headquarters

P.O. Box 1943 • Birmingham, AL 35201 (205) 991-6600

\section{CONTACT US TODAY TO LEARN MORE.}




\section{Omnigraphies REFERENCE PÚBLICATIONS}

\section{Exclusive}

\section{U.S. Distributor}

of St. Paul's

\section{Bibliographies}

Omnigraphics, Inc. has been named exclusive North American distributor of select titles from the collection of St. Paul's Bibliographies, Winchester, England. Acclaimed by scholars of English literature, librarians, bibliophiles, and book collectors, these books are ranked among the most important bibliographic reference materials ever published.

\section{Pioneers in Bibliography}

Edited by Robin Myers and Michael Harris. 117 pages. List of contributors. 1988. $\$ 50$

The product of an annual conference on book trade history at the University of London, this book contains several essays about bibliographers, their works, and the physical description and analyses of texts dating from medieval libraries up to the works of today's researchers.

Available on 60-day approval. $10 \%$ discount on standing orders.

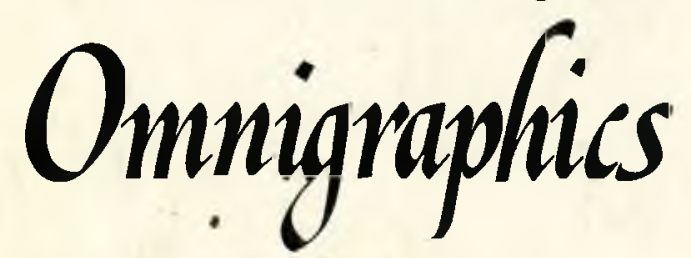

Penobscot Building

Detroit, MI 48226

Fax: 313-961-1383

Toll-free phone: 800-234-1340

\section{PRINCIPLES OF BIBLIOGRAPHICAL DESCRIPTION}

By Fredson Bowers. Second edition. 505 pages. Foreword. Appendices. Index. 1986. $\$ 70$

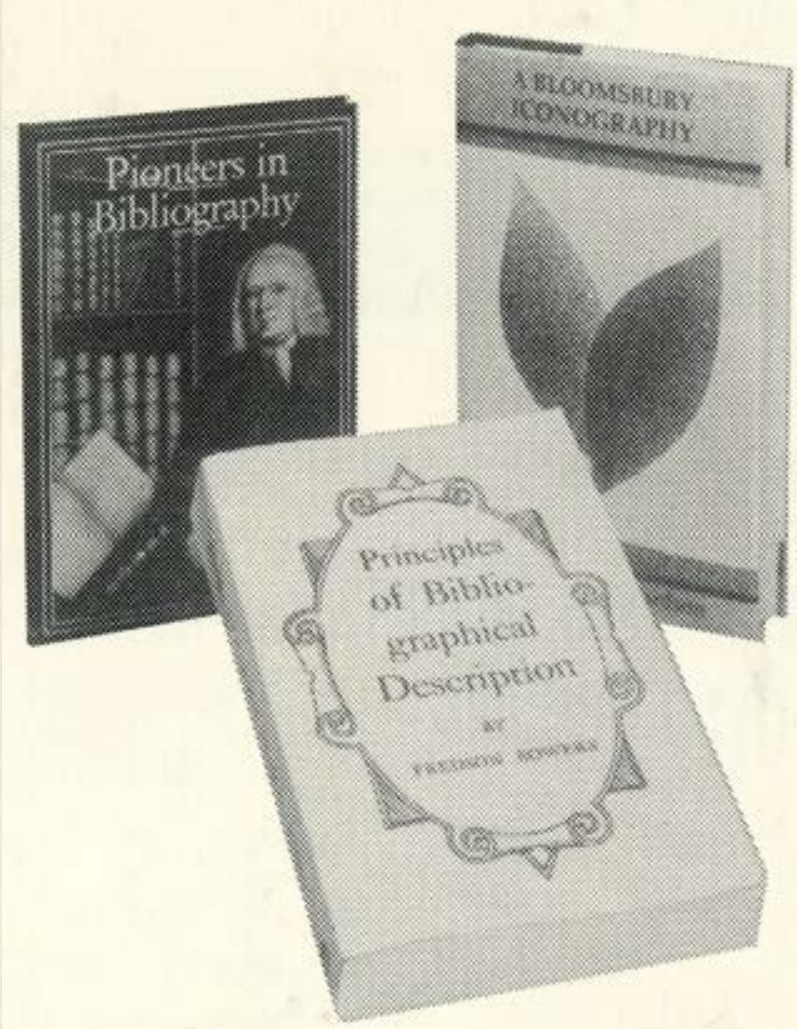

An exhaustive work that has estab: ed itself as an indispensable source to all concerned with the history and description of publishing texts. It deals with books from the days of the handpress to the present time. Of special interest to librarians whose work depends on bibliographic description.

\section{Additional St. Paul's} Titles Now Available

Aspects of Printing: From 1600. By Robin Myers and Michael Harris. 1987. $\$ 40$

Bibliography of British Gardens. By Ray Desmond. 1989. \$66

A Bibliography of Dr. John Donne, Dean of St. Paul's. By Geoffrey Keynes, Kt. 1973. $\$ 80$
A Bibliography of the Foulis Press. By Philip Gaskell. 1986. \$84

A Bibliography of Henry King, D.D., Bishop of Chichester. By Geoffrey Keynes, Kt. 1977. $\$ 60$

A Bibliography of Edward Jenner. By William LeFanu. 1985. \$60

Bibliography of William Hazlett. By Geoffrey Keynes, Kt. 1981. \$40

A Bibliography of Lucretius. By Cosmo A. Gordon. 1985. $\$ 70$

A Bibliography of the Works of Sir Winston Churchill, KG, OM, CH. By Frederick Woods. 1979. $\$ 60$

A Bloomsbury Iconography. By Elizabeth P. Richardson. 1989. \$84

The Botanists. By David E. Allen. 1986. $\$ 40$

A Britten Source Book. By John Evans, Phillip Reed, Paul Wilson. 1987. \$75

The Children's Books of Mary (Belson) Elliott. By Marjorie Moon. 1987. \$70

The Country House Described. By Michael Holmes, 1986. $\$ 80$

From Writer to Reader. By Philip Gaskell. 1984. Softcover, $\$ 31$; Hardcover, $\$ 50$

George Borrow. By Michael Collie and Angus Fraser. 1984. $\$ 60$

Gerard Manley Hopkins. By Tom Dunne. 1978. $\$ 65$

John Harris's Books for Youth, 1801-1843. By Marjorie Moon. 1976. $\$ 70$

A.E. Housman. By John Carter and John Sparrow. 1982. $\$ 40$

Library Catalogues of the English Renaissance. By Sears Jayne. 1983. $\$ 60$

The Printing and Proof-Reading of the First Folio of Shakespeare. By Charles Hinman. 2 vols. 1963. \$200/set

Sir Joseph Banks, 1743-1820. By Harold B. Carter. 1987. $\$ 100$

The Works of Charles Darwin. By R.B. Freeman. 1977. $\$ 50$

. . . and more. 